2003

\title{
Is There a Role for Lawyers in Preventing Future Enrons
}

Jill E. Fisch

Kenneth M. Rosen

Follow this and additional works at: https://digitalcommons.law.villanova.edu/vlr

Part of the Business Organizations Law Commons, and the Legal Ethics and Professional Responsibility Commons

\section{Recommended Citation}

Jill E. Fisch \& Kenneth M. Rosen, Is There a Role for Lawyers in Preventing Future Enrons, 48 Vill. L. Rev. 1097 (2003).

Available at: https://digitalcommons.law.villanova.edu/vlr/vol48/iss4/5

This Symposia is brought to you for free and open access by Villanova University Charles Widger School of Law Digital Repository. It has been accepted for inclusion in Villanova Law Review by an authorized editor of Villanova University Charles Widger School of Law Digital Repository. 


\title{
IS THERE A ROLE FOR LAWYERS IN PREVENTING FUTURE ENRONS?
}

\author{
JILL E. FISCH* \\ KENNETH M. ROSEN**
}

\begin{abstract}
Following the collapse of the Enron Corporation, the ethical obligations of corporate attorneys have received increased scrutiny. The Sarbanes-Oxley Act of 2002, enacted in response to calls for corporate reform, specifically requires the Securities and Exchange Commission to address the lawyer's role by requiring covered attorneys to "report up" evidence of corporate wrongdoing to key corporate officers, and, in some circumstances, to the board of directors. Failure to "report up" subjects a lawyer to liability under federal law.

This Article argues that the reporting up requirement reflects a second-best approach to corporate governance reform. Rather than focusing on the actors that traditionally control a corporation's activities, the statute attempts to solve governance problems indirectly by assigning to the lawyer the role of corporate gatekeeper and information intermediary. We demonstrate that the reporting up requirement fails to address the incentives that motivate corporate attorneys, directors and managers. At the same time, the provision threatens to undermine the flow of information between lawyers and corporate actors. As a consequence, we suggest that the requirement is unlikely to achieve its objective of providing key corporate decisionmakers with early information about potential misconduct. Moreover, attorney and manager responses to the reporting up requirement are likely to reduce the quality of legal services provided to the corporation.
\end{abstract}

Based on this cost-benefit analysis, we conclude that the Sarbanes-Oxley approach to corporate governance reform is flawed. Instead, we argue that a demand side approach is more likely to realign corporate attorney incentives and to reinvigorate the business lawyer's important role in promoting good corpo-

* Professor and Director, Center for Corporate, Securities and Financial Law, Fordham Law School. The authors would like to thank Robert Marel for research assistance.

** Assistant Professor, The University of Alabama School of Law. Professor Rosen previously served as Fellow, Center for Corporate, Securities and Financial Law, Fordham Law School. 
rate governance. Toward that end, we identify specific reforms tailored to increasing the incentives for corporate officers and directors to demand and obtain better legal advice.

\section{INTRODUCTION}

$\mathrm{T}$ HE collapse of Enron Corporation and, perhaps more importantly, the stock market reaction to the improprieties uncovered at Enron and several other large public companies triggered a re-evaluation of corporate governance in the United States. Over the course of several months, Congressional hearings considering how to improve securities disclosure and corporate decision-making in order to prevent future scandals became regular events on Capitol Hill. Even with a politically divided Congress, agreement was reached rapidly on broad financial reform legislation-the Sarbanes-Oxley Act of 2002 ("Sarbanes-Oxley" or "the Act"). ${ }^{1}$ Upon signing this legislation, President George W. Bush declared that the statute contained "the most far reaching reforms of American business practices since the time of Franklin Delano Roosevelt."2

That the failure of a corporation triggered a legislative response is not surprising. Corporate scandals often result in a spate of policy-making. What may be more surprising is the attention given to the role of attorneys in the current corporate crisis. After a hearing earlier this year where Senators called a panel of Enron's in-house and outside counsels to task, one commentator noted that no one could remember a hearing specifically focusing on the lawyer's role. ${ }^{3}$ Section 307 of the new statute requires the U.S. Securities and Exchange Commission ("SEC" or "Commission") to develop rules setting forth minimum standards of conduct for lawyers appearing before the Commission, including an affirmative obligation for lawyers to "report up" evidence of corporate misconduct. ${ }^{4}$ Importantly,

1. Sarbanes-Oxley Act of 2002, Pub. L. No. 107-204, 116 Stat. 745 (2002).

2. President George W. Bush, The East Room, The White House, President Bush Signs Corporate Corruption Bill, at www.whitehouse.gov/news/releases/2002/ 07/print/20020730.html (July 30, 2002).

3. Otis Bilodeau, Vinson Partner Defends His Firm, His Integrity, Recorder, Mar. 21,2002 , at 3 .

4. On November 21, 2002, the SEC proposed rules under Section 307. See Implementation of Standards of Professional Conduct for Attomeys, Securities Act Release No. 33-8150 (Nov. 21, 2002) [hereinafter Proposed SEC Rules], available at http:// www.sec.gov/rules/proposed/33-8150.htm. The SEC's proposed rules, in many ways, imposed broader obligations than those mandated by Section 307. See ABA Urges SEC Not to Exceed Sarbanes-Oxley Mandate without Extended Comment Period, at http://www.manningproductions.com/ABA257/ABA257_NewsRelease.htm (Dec. 18, 2002) (describing call by ABA President Alfred P. Carlton, Jr. on SEC to defer proposals regulating lawyer conduct that go beyond specific statutory mandate). Subsequently, the SEC adopted a portion of its original proposal, with some modifications. See Implementation of Standards of Professional Conduct for Attorneys, Securities Act Release No. 33-8185 (Jan. 29, 2003) [hereinafter Adopted SEC Rules], available at http://www.sec.gov/rules/final/33-8185.htm. As this Article went to press, the SEC's proposed rule requiring attorneys to report evidence of 
the obligations will now have the force of federal law, ${ }^{5}$ including the potential that violations will be subject to SEC enforcement proceedings. ${ }^{6}$

Perhaps the spotlight on lawyers should not be surprising. Based on facts reported by the press and revealed in various documents and hearings, the actions of Enron's attorneys invited scrutiny. According to the allegations, Enron's attorneys not only blessed potentially fraudulent transactions, but also conducted an investigation largely viewed as a whitewash. Moreover, courts and commentators have long questioned the appropriate governance role of the corporate attorney. Some of the earliest commentators on U.S. corporate and securities law focused on the relationship between companies and lawyers. ${ }^{7}$ As the role of attorneys has evolved, there have been repeated attempts to impose special obligations on corporate attorneys. Such efforts parallel periodic calls for broader reforms of corporate governance.

Clearly the compulsory "reporting up" required by Section 307 is meant to answer the call for reform following Enron's collapse by providing an invigorated role for lawyers as gatekeepers. Whether this role is appropriate $^{8}$ and whether Sarbanes-Oxley will be effective in achieving it remain to be seen. ${ }^{9}$ In part, the effectiveness of Section 307 will depend

misconduct out to the SEC was still pending. See Implementation of Standards of Professional Conduct for Attorneys, Securities Act Release No. 33-8186 (Jan. 29, 2003 [hereinafter Proposed Reporting Out Rule], available at http://www.sec.gov/ rules/proposed/33-8186.htm.

5 . Notably the SEC's new rules explicitly provide that a violation of the standards of professional conduct "shall be treated for all purposes in the same manner as a violation of the Securities Exchange Act of $1934 \ldots$ and shall be subject to the same penalties and remedies." Adopted SEC Rules, supra note 4, at $\$ 205.6$ (a).

6 . The significance of the new exposure to liability is increased by the simultaneous inclusion, in Sarbanes-Oxley, of Section 602, which increases the SEC's authority to censure and disbar professionals, including attorneys, from practice before the Commission. See Sarbanes-Oxley Act, § 307 .

7. See generally William W. Cook, A Treatise on Stock and Stockholders and General Corporations law as Applicable to Railroad, Banking, Insurance, Manufacturing, Mining, Telegraph, Telephone, Express, Gas, Commercial, Business, Turnpike, Bridge, Canal and Other Private Corporations (1889); Clark and Marshall, Marshall on the Law of Private Corporations (1912); William Allen Wood, Modern Business Corporations (1917).

8. Gatekeeping is not a costless enterprise. See generally Reiner H. Kraakman, Gatekeepers: The Anatomy of a Third-Party Enforcement Strategy, 2 J.L. ECON. \& OrG. 53, 61-87 (1986) (proposing criteria for evaluating gatekeeping strategies, including costs of gatekeeping).

9. Although past ethics debates inform our analysis, this Article evaluates the issue from the perspective of the business lawyer. Such a perspective is important as Sarbanes-Oxley moves the attorney conduct issue squarely into the realm of the federal securities laws. Accordingly, the Article's discussion of attorneys as "gatekeepers" focuses on their potential role as control mechanisms for a corporation's governance system. The Article does not take on the normative issues of whether a lawyer's role is that of a public servant and whether a corresponding duty exists to impose higher moral standards on lawyers through professional responsibility rules. Cf. generally, Russell G. Pearce, Model Rule 1.0: Lawyers Are Morally Accountable, 
on the scope of SEC rulemaking efforts that are currently in progress, ${ }^{10}$ as well as the enforcement policies adopted by the SEC with respect to the new rules. This Article, however, sounds an early note of caution. In particular, this Article criticizes the decision in Sarbanes-Oxley to implement procedural reforms without evaluating more carefully the normative and practical constraints on the lawyer's role.

To determine whether Sarbanes-Oxley takes the correct approach to attorney obligations, we first identify the regulatory background to Section 307. "' One key element is the continuing debate about the attorney's role, specifically the tension between the lawyer's obligations to the client and the lawyer's ability to serve as gatekeeper. A second component is the SEC's historical reluctance to police lawyer misconduct through enforcement of the federal securities laws. A third factor is the limited availability, under current law, of malpractice remedies and other private civil litigation as a means to address the lawyer's role in assisting clients who engage in securities fraud. In sum, the regulatory background reveals few aggressively enforced checks on lawyer misconduct-a structure that, fairly or not, was actively criticized after the collapse of Enron.

The Article next turns to the recent regulatory reform. ${ }^{12}$ A thorough understanding of such reform requires an analysis of its benefits and costs. On the benefits side, we consider the proffered justifications for the re-

70 FORDHAM L. REv. 1805, 1805-09 (2002) (advocating new professional responsibility rule to force lawyers to consider their conduct's moral implications).

Nor, absent a complete set of facts, does the Article determine whether Enron's attorneys failed to report information required by the rules of professional conduct. Cf. Stanley S. Arkin, Corporate Responsibility Legislation: Conflicts, Uncertainties, N.Y. LAw., Aug. 8, 2002, at 3 (noting bar rules allow flexibility for attorney acting in interest of corporation). See also Remarks at First Annual Ethics Award, Metro. Corp. Couns., Oct. 20, 2002, at 16 (quoting E. Norman Veasey, Chief Justice of Delaware, remarks at First Annual Ethics Award at Annual Ethics Marathon of New York Chapter of American Corporate Counsel Association, Sept. 18, 2002):

[I]f a lawyer for the corporation comes to know that the CFO has perpetrated some potentially fraudulent shenanigans with 'creative accounting,' existing Model 1.13 kicks in. Under the rule, the lawyer 'shall proceed as is reasonably necessary in the best interests of the organization.' In determining how to proceed, he 'shall give due consideration to the seriousness of the violation and its consequences' and a number of other issues that call on the lawyer's exercise of judgment. A proper reading of Model Rule 1.13 makes it clear that in the serious corporate fraud case, in my opinion, the lawyer must act promptly to prevent fraud by going up the chain of command to the board of directors, if necessary. Id. (quoting Veasey).

10. See Proposed Reporting Out Rule, supra note 4. Because the SEC's rulemaking is an ongoing process and remains subject to change, this Article focuses on the statutory mandate rather than the details of its implementation. The reporting out proposal, however, may exacerbate issues raised by this Article and prompt additional concerns.

11. For further discussion of regulatory background to Section 307 , see infra notes $18-45$ and accompanying text.

12. For further discussion of reforms enacted in response to Enron scandal, see infra notes 46-55 and accompanying text. 
form, focusing on the criticisms of the lawyers that represented Enron. Section 307's reporting up requirement, we argue, is an attempt to force corporate attorneys to act as information intermediaries. The statute is based on the model of attorney as gatekeeper, with the premise that forcing attorneys to provide more information to corporate decisionmakers will improve the resulting quality of corporate decisions.

We then consider the likely effectiveness of the new legislation in improving information flow and, hence, corporate decision-making. ${ }^{13}$ After identifying a number of flaws in the statute that are likely to hamper its workability, we argue that the reform's central premise-that mandated disclosure will qualitatively increase information flow to corporate boards and to the securities markets-is flawed. Extending our observations about the tension in the role of the corporate lawyer, we argue that unless there are substantial changes to this role and to the incentives under which the lawyer operates, ${ }^{14}$ "reporting up" is unlikely to be an effective response to the types of problems experienced at Enron.

Moreover, Section 307's poor prospects for success are accompanied by tangible costs. Implementation of mandatory "reporting up" rules threatens to reduce quality information flow between corporate attorneys and their clients. While we do not dispute the value of attorneys reporting evidence of corporate wrongdoing to the general counsel and the board, we argue that mandatory rules, backed by the threat of SEC sanctions, may be counterproductive as a tool for increasing the effectiveness of client representation. ${ }^{15}$ Similarly, we argue that Section 307 is misguided in its attempt to improve corporate governance through changes in lawyer behavior. ${ }^{16}$ This approach, which can fairly be characterized as a secondbest solution, is inconsistent with the existing financial and other constraints on the lawyer's ability to act as an independent gatekeeper.

Instead, the Article argues that effective reform can be better accomplished through demand side changes to the obligations of corporate decisionmakers. ${ }^{17}$ If corporate officials demand better information from their lawyers, market pressures will reinforce, rather than conflict with, lawyers' ethical obligations. Accordingly, the Article identifies several demand side regulatory reforms that offer potential first-best solutions. Although our discussion of these reforms is preliminary, we argue that reform efforts will be more effective if they are targeted at boards and senior corporate officers, requiring them to obtain greater information from their lawyers.

13. For further discussion of the likely effectiveness of the new legislation, see infra notes 66-103 and accompanying text.

14. In discussing these issues we focus primarily on outside corporate counsel.

15. For further discussion of disadvantages of mandatory reporting rules, see infra notes 105-24 and accompanying text.

16. For further discussion of the flaws behind enlisting lawyers as gatekeepers, see infra notes $125-28$ and accompanying text.

17. For further discussion of alternatives to the existing regulatory approach, see infra notes 129-52 and accompanying text. 
Placing the incentive to obtain information in the hands of those who are in a position to evaluate and reward lawyer services is more likely to lead to an improved corporate ethic.

\section{Regulatory Background and the Corporate Lawyer}

\section{A. The Lawyer's Role}

The role of a corporate lawyer has been the subject of two competing visions: the hired gun or total commitment model and the gatekeeper model. ${ }^{18}$ The choice between the models has important normative implications for the attorney's obligations. ${ }^{19}$ At its core, the hired gun model is based on a strong version of client primacy. The attorney is affirmatively required to assist his or her client to the fullest extent permitted by law. The gatekeeper model incorporates public policy limitations on attorney conduct that may constrain an attorney from following some client instructions even if those instructions are legal. In addition, the model may require the attorney to take affirmative steps to prevent or limit client wrongdoing.

Scholars in a range of disciplines have debated the extent to which an attorney should be permitted or required to disclose corporate misconduct, either to a higher authority within the corporation, or to outside authorities. Hired gun advocates argue that disclosure obligations are inconsistent with the lawyer's role and undermine his capacity to serve the best interests of his client. ${ }^{20}$ Gatekeeper proponents argue that a narrow insistence on client primacy is inconsistent with the profession's obligations to the public.

18. See, e.g., Paul G. Haskell, Why Lawyers Behave As They Do 85-86 (1998) (describing both models).

19. Perhaps these two standard models captured the nature of attorney services at some point in time; perhaps they still reflect the available options in some contexts, such as litigation. Today, however, the range of activities in which the modern corporate lawyer is engaged suggests a correspondingly broader range of roles. At a minimum, modern practice introduces the idea of the attorney as problem solver, called upon to devise a way of accomplishing a client-specified objective, consistent with existing legal constraints; the attorney as intermediary, mediating between participants in an effort to reach a common objective; and the attorney as business adviser, offering guidance on corporate decision-making that incorporates legal and non-legal perspectives. In addition, some commentary has suggested that attorneys should be publicly accountable in a role that extends beyond gatekeeper to perhaps policeman, charged with monitoring client legal compliance and reporting clients who systematically fail to adhere to legal standards.

20. See, e.g., Monroe H. Freedman, Understanding Lawyers' Ethics 7 (1990)

I would identify the client . . . as 'this other person whom I have the power to help.' In that view, the central concern of lawyers' ethics is not ... how my client 'can be made as good as possible.' Rather, it is how far I can ethically go-or how far I should be required to go-to achieve $I d$. for my client full and equal rights under law. 
The hired gun model has been the dominant influence on state ethics rules. In particular, Model Rule 4.1 of the American Bar Association's ("ABA") Model Rules of Professional Conduct prohibits a lawyer from making false statements or material omissions to third parties. Rule 4.1's prohibition is partially limited, however, by Rule 1.6, which imposes a duty of confidentiality. ${ }^{21}$ The scope of this limitation varies. Thirty-seven states have adopted a version of Rule 1.6 that permits but does not require a lawyer to disclose confidential information to prevent a client's criminal fraud; four states require such disclosure, and nine states and the District of Columbia forbid such disclosure. ${ }^{22}$

Nonetheless, the existing model rules provide several important constraints on the lawyer's role that are relevant to the wrongdoing at Enron. In particular, Rule 1.2 provides that a lawyer shall not counsel a client to engage or assist a client in criminal or fraudulent conduct. More generally, Rule 1.13 governs the obligations of a lawyer who represents an organization. Importantly, Rule 1.13 explicitly provides that the lawyer's obligation runs to the organization rather than to individual persons within that organization, such as corporate management. In addition, the Rule specifies procedures for a lawyer who knows of corporate misconduct. The Rule permits but does not require the lawyer to ask for reconsideration of the matter, to ask for a separate legal opinion or to refer the matter to higher authority in the organization. If despite the lawyer's efforts, the organization persists in violation of the law, the lawyer is permitted to resign. In its current form, however, Rule 1.13 arguably does not require the lawyer to undertake any specific action, including reporting up. ${ }^{23}$

Separate from the issue of the content of the Model Rules is how well these rules are enforced. Some perceive states as inadequately enforcing their versions of the rules of professional conduct. ${ }^{24}$ In a speech to mem-

21. As originally proposed, Rule 4.1 would have required that based on requirements imposed by "other laws." See Geoffrey C. Hazard, Jr. \& W. William Hodes, The Law of Lawyering $\$ 37.2-37.6$ (3d ed. 2003) (describing Rule 4.1 as originally promulgated by Kutak Committee). Subsequently, the rule was modified to reduce the disclosure obligation. Indeed, Comment 21 to Model Rule 1.6 now provides, "Whether another provision of law supersedes Rule 1.6 is a matter of interpretation beyond the scope of these Rules, but a presumption should exist against such a supersession." Thomas D. Morgan \& Ronald D. Rotunda, 2002 Selected Standards on Professional Responsibility 22 (2002).

22. See Attorneys' Liability Assurance Society, Inc., Ethics Rules on Client Confidences (2001), reprinted in MORGAN \& RotUnDA, supra note 21, at 134-44.

23. See, e.g., Working Group on LaWyers' Representation of Regulated Clients, ABA Report to the House of Delegates 2 (1993) (describing Office of Thrift Supervision's theory that lawyers have obligation to "report up" to board of directors as "novel theor[y] of professional responsibility").

24. Complaints about inadequate disciplinary enforcement are longstanding. See, e.g., American Bar Association Committee on Evaluation of Disciplinary Enforcement, Problems and Recommendations in Disciplinary Enforcement-Final Draft (1970), available in Geoffrey C. Hazard, Jr. \& Deborah L. Rhode, The Legal Profession: Responsibility and Regulation 484-87 (2d ed. 1988) (noting that 
bers of the American Bar Association, SEC Chairman, Harvey Pitt, complained of "the generally low level of effective responses we receive from state bar committees when we refer possible disciplinary proceedings to them."25 Although it is unclear why the number of enforcement actions has been limited, ${ }^{26}$ frustration with state authorities likely fostered the environment in which Section 307 was drafted.

\section{B. The Lawyer's Obligations with Respect to Corporate Misconduct}

The Enron case has raised questions about the nature and scope of a lawyer's obligations when the lawyer is aware of the possibility that the corporation or members of its management are engaging in misconduct. This Article explicitly focuses on instances of misconduct by corporate management in which the lawyers play, at most, a secondary role. The purpose of this focus is twofold. First, existing ethical rules as well as state and federal law provide ample prohibitions on attorneys engaging in fraud. To the extent that attorneys engage in fraud in violation of existing law, regulatory refinements are unlikely to alter their behavior substantially. Second, debate about Enron and other recent scandals emphasizes the potential ability of lawyers to constrain management misconduct. The argument is not that the lawyers engineered a massive fraud, but rather that different lawyer behavior might have prevented or stopped fraudulent activity by management. Thus, the emphasis here is on the effectiveness of lawyers acting as gatekeepers.

Historically, gatekeeping obligations have been imposed on corporate lawyers in several ways. Some cases have permitted malpractice claims premised on the theory that an attorney's negligence assisted or failed to stop management misconduct. For example, the court in FDIC v. Clark, ${ }^{27}$ specifically found that the client's attorneys could be liable for malpractice, under Colorado law, for failing to disclose fully allegations of officer misconduct to the client's board of directors. ${ }^{28}$ The scope of relief available through malpractice claims is somewhat limited, however, because such claims must typically be brought by a trustee or receiver, such as the Fed-

"[d]isciplinary action is practically nonexistent in many jurisdictions"); see also George C. Harris, Taking the Entity Theory Seriously: Lawyer Liability for Failure to Prevent Harm to Organizational Clients Through Disclosure of Constituent Wrongdoing, 11 Geo. J. Legal Ethics 597, 660 (1998) ("Particularly given the infrequency of enforcement of professional conduct rules, it is safe to assume that those rules have marginal effect on lawyer behavior, at least as compared to standards of liability.").

25. See Harvey L. Pitt, Speech by SEC Chairman: Remarks Before the Annual Meeting of the American Bar Association's Business Law Section (Aug. 12, 2002), available at http://www.sec.gov/news/speech/spch579.htm. (claiming that state bars do not act vigorously on SEC attorney referrals); BNA, SEC Will Seek Discipline of Lawyers if State Bars Don't, Sept. 25, 2002.

26. One possible explanation is that the rules are generally followed. Another is that cases of violation are difficult to prove, especially when prosecutorial resources are limited.

27. 978 F.2d 1541 (10th Cir. 1992).

28. See id. at 1549-54 (discussing liability of attorneys). 
eral Deposit Insurance Corporation; the client may then be barred from recovery by imputation of its employees' wrongdoing. ${ }^{29}$

A second mechanism for imposing gatekeeping obligations on securities lawyers has been SEC enforcement. The SEC has long enjoyed the power to discipline professionals, including attorneys. In SEC $v$. National Student Marketing, ${ }^{30}$ the SEC took the position that lawyers who knew that their client had entered into a merger by making materially misleading disclosures had an affirmative duty to prevent the merger. ${ }^{31}$ The SEC's statements about the lawyer's role and, in particular, its suggestion that lawyers had an obligation to blow the whistle on a client, were highly controversial. One commentator described the SEC's complaint in National Student Marketing as "the best-read document since "Gone with the Wind.""32

The SEC expanded on its efforts in In re Carter ("Carter and Johnson"), taking advantage of its authority over attorneys practicing before the Commission under its Rules of Practice. ${ }^{33}$ In Carter and Johnson, in the context of an administrative proceeding, the SEC stated that a lawyer who is aware of a client's continuing and substantial violations of the securities laws is required to "take prompt steps to end his client's noncompliance." In particular, the SEC expressly stated that an attorney's obligations could include reporting evidence of management misconduct to the board of directors or the Commission, and that failure to take appropriate action could subject the lawyer to sanctions.

These attempts by the SEC to require lawyers to address client misconduct prompted a widespread and highly critical response from the bar. The ABA questioned whether the SEC had the authority to adopt any standards of professional conduct for lawyers and stated that the SEC was inappropriately trying to become a "putative bar association." 34 The SEC retreated from its efforts to increase lawyer discipline. In 1982, SEC General Counsel Edward Greene suggested that the SEC would henceforth exercise prosecutorial restraint in bringing administrative proceedings

29. As a practical matter, the effects of malpractice may be limited by whether participants in the wrongdoing are replaced. Managerial wrongdoers are unlikely to initiate malpractice actions against attorneys for failure to reveal and to stop those managers' malfeasance. However, attorneys must account for such a possibility in considering whether to aid malfeasance through inaction.

30. 457 F. Supp. 682 (D.D.C. 1978).

31. See id. at 714-15 (describing SEC's position that attorney had an obligation to delay or even "undo" the merger).

32. See Roberta S. Karmel, Attomey's Securities Laws Liabilities, 27 Bus. Law. 1153, 1153 (1972) (citing Green, Irate Attorneys: A Bid to Hold Lawyers Accountable to Public Stamp, Angers Firms, Wall St. J., Feb. 15, 1972, at 1).

33. In re William R. Carter \& Charles J. Johnson, Jr., [1981 Transfer Binder] Fed. Sec. L. Rep. (CCH) I 82,847, 1981 SEC LEXIS 1940 (1981).

34. See SEC Standard of Conduct for Lauyers: Comments on the SEC Rule Proposal, 37 Bus. Law. 915, 924 (1982). 
against lawyers under SEC Rule 102(e) ${ }^{35}$ The SEC generally would bring such proceedings only in cases in which a court had previously determined that the lawyer violated the federal securities laws. ${ }^{36}$ The requirement of an independent court decision was widely viewed as striking a balance between the concerns of the SEC and the Bar. ${ }^{37}$ Nonetheless, the requirement had the effect of virtually eliminating SEC disciplinary actions against lawyers. ${ }^{38}$

A third alternative has been private litigation against lawyers for aiding and abetting their clients' securities fraud. Although litigation efforts against lawyers have traditionally been more limited than those against other secondary actors, such as accountants and investment bankers, plaintiffs pursued and, in some cases successfully obtained, money judgments against lawyers who substantially assisted client fraud. These efforts were undercut by a variety of restrictions on the scope of private securities litigation, most importantly the Supreme Court's decision in Central Bank v. First Interstate, ${ }^{39}$ which held that SEC Exchange Act Rule $10 \mathrm{~b}-5^{40}$ did not provide a private right of action for aiding and abetting securities fraud. ${ }^{41}$

35. Edward Greene, Lawyer Disciplinary Proceedings Before the Securities and Exchange Commission, 14 SEC. REG. \& L. ReP. (BNA) 168 (1982). SEC Rule 102(e) is the successor to the Commission's earlier Rule of Practice 2(e), and provides for administrative proceedings against attorneys practicing before the Commission. See SEC Rules of Practice, 17 C.F.R. \$ 201.102(e) (2002). Prior to Greene's comments, Ralph Ferrara, another SEC General Counsel, delineated the limits of the old Rule 2(e):

It is, however, perhaps just as important to address what Rule $2(\mathrm{e})$ is not:

It is not an alternative enforcement remedy to be used in lieu of Commission injunctive actions, criminal referrals, section 21 (a) reports, administrative proceedings under section 15(c)(4) of the Exchange Act, or the like. Moreover, it is not a vehicle to regulate the professional responsibilities of the securities bar. Nor is it an attempt to set admission standards for practice before the Commission. Finally, it is not a vehicle to require the private bar 'to blow the whistle' on its clients. The Rule is essentially an effort by the Commission to protect the integrity of its own processes and, in turn, the investing public from unethical or dishonest activities by professionals. As such, it is certainly a legitimate, reasonable adjunct of the Commission's existing statutory authority.

Ralph C. Ferrara, Administrative Disciplinary Proceedings Under Rule 2(e), 36 Bus. LAw. $1807,1807-08$ (1981).

36. See Greene, supra note 35. The SEC's position was formalized in Exchange Act Release No. 25893 (1988).

37. See Ann Maxey, SEC Enforcement Actions Against Securities Lauryers: New Remedies us. Old Policies, 22 Del. J. Corp. L. 537, 543 (1997) (describing requirement of court judgment as allaying fears of potential abuse).

38. See, e.g., Robert W. Emerson, Rule 2(e) Revisited: SEC Disciplining of Attomeys Since In re Carter, 29 Am. Bus. L.J. 155, 213 (1991) (observing that, since Carter and Johnson, virtually all Rule 2(e) proceedings against lawyers have followed federal court finding of securities law violation).

39. 511 U.S. 164 (1994).

40. 17 C.F.R. $\$ 240.10$ b-5 (2002). 10(b)).

41. See Central Bank, 511 U.S. at 191 (ruling based on plain reading of Rule 
Although plaintiffs have continued with the enforcement efforts against lawyers, alleging in some cases that the lawyers were liable as primary violators, ${ }^{42}$ Congressional enactment of the Private Securities Litigation Reform Act of 1995 ("PSLRA") further hampered private litigation. ${ }^{43}$ The PSLRA explicitly reaffirmed the SEC's right to bring an enforcement action for aiding and abetting federal securities fraud, however. The efficacy of such litigation was affirmed in SEC $v$. Fehn, ${ }^{44}$ where the United States Court of Appeals for the Ninth Circuit upheld an SEC action against an attorney. ${ }^{45}$ Thus, aiding and abetting fraud is still a punishable offense.

\section{Post-Enron Developments}

Events at Enron catalyzed several recent efforts to reexamine the role and liability exposure of the corporate lawyer. Following public reports about the role of Enron's lawyers, Professor Richard Painter, joined by forty other law professors, called for the SEC to adopt a rule requiring corporate lawyers who are aware of client misconduct to report that misconduct to the board of directors. ${ }^{46}$ Painter suggested that the rule expressly require that the lawyer "go up the ladder all the way to the board of directors." 47 SEC General Counsel David Becker responded to the Painter letter by indicating that the SEC would adhere to the "strong view among the bar that these matters are more appropriately addressed by state bar rules." 48 This response appears to have been one factor triggering congressional action in Sarbanes-Oxley. ${ }^{49}$

The private bar reacted to the Enron scandal by forming the $A B A$ Task Force on Corporate Responsibility. In a preliminary report issued on July 16, 2002, the Task Force proposed changes in Rules 1.2 (scope of

42. See, e.g., Jill E. Fisch, The Scope of Private Securities Litigation: In Search of Liability Standards for Secondary Defendants, 99 Colum. L. Rev. 1293, 1300-03 (1999) (describing post-Central Bank efforts to proceed against secondary actors as primary violators).

43. The PSLRA accomplished this, in part, by imposing stricter pleading standards and proportionate liability rules for private securities litigation.

44. 97 F.3d 1276 (9th Cir. 1996), cert. denied, 522 U.S. 813 (1997).

45. See id. at 1280 (summarizing judgment).

46. Letter from Richard Painter, Professor, University of Illinois College of Law, to SEC (March 7, 2002) (on file with authors); see also Richard W. Painter \& Jennifer E. Duggan, Lawyer Disclosure of Corporate Fraud: Establishing a Firm Foundation, 50 SMU L. REv. 225 (1996) (discussing 1995 Reform Act's lack of articulated rules for lawyers confronted with corporate fraud).

47. Letter from Painter to SEC, supra note 46.

48. Letter from David Becker, General Counsel, Securities Exchange Commission, to Richard Painter (March 28, 2002) (on file with authors).

49. See Letter from John Edwards, Senator of North Carolina, to Harvey Pitt, Chairman, Securities Exchange Commission (June 18, 2002), reprinted in 148 CoNG. Rec. S5652-53 (daily ed. June 18, 2002) (statement of Sen. Edwards) [hereinafter Letter from Edwards] (referencing Becker letter and soliciting Pitt's assistance in drafting legislation that would impose duty on lawyers to report client misconduct to board of directors). 
representation); 1.6 (confidentiality); 4.1 (truthfulness in statements to third parties) and 1.13 (organization as client). ${ }^{50}$ Among other things, the Task Force recommended changes that would require corporate lawyers who reasonably should know of client misconduct to disclose the misconduct to higher corporate authorities, including, in some cases, the board of directors. ${ }^{51}$ In addition, the Task Force recommended that lawyers be permitted to disclose client confidences in order to stop or prevent corporate crime or fraud and that lawyers be affirmatively required to disclose confidential information when necessary to prevent client crime involving the lawyer's services. ${ }^{52}$

At the same time, in July 2002, Congress enacted and President Bush signed the Sarbanes-Oxley Act of 2002. Sarbanes-Oxley is a broad response to perceived failures in corporate governance and financial accountability, as well as an effort to restore confidence to the financial markets in the wake of their tumultuous reaction to repeated reports of corporate wrongdoing. The statute addresses a range of issues, including auditor independence, enhanced financial disclosures, analyst conflicts of interest, criminal enforcement and corporate accountability. ${ }^{53}$ The Act also contains the first Congressional effort to specify the obligations of securities lawyers.

Section 307 of the Act provides:

Not later than 180 days after the date of enactment of this Act, the [Securities and Exchange] Commission shall issue rules, in the public interest and for the protection of investors, setting forth minimum standards of professional conduct for attorneys appearing and practicing before the Commission in any way in the representation of issuers, including a rule-(1) requiring an attorney to report evidence of a material violation of securities law or breach of fiduciary duty or similar violation by the company or any agent thereof, to the chief legal counsel or the chief executive officer of the company (or the equivalent thereof); and (2) if the counsel or officer does not appropriately respond to the evidence (adopting, as necessary, appropriate remedial measures or sanctions with respect to the violation), requiring the attorney to report the evidence to the audit committee of the

50. See Preliminary Report of the American Bar Association's Task Force on Corporate Responsibility 47-50 (July 16, 2002), available at http://www.abanet.org/buslaw/ corporateresponsibility/preliminary_report.pdf. [hereinafter "ABA Preliminary Report"].

51. See id. at 27-30 (recommending amendment to Rule 1.13 to make clear lawyer's responsibility to report corporate misconduct to senior officers or Board of Directors).

52. See id. at 30-35 (recommending that disclosure of confidences become mandatory instead of permissive).

53. See generally James Hamilton \& Ted Trautman, Sarbanes-Oxley Act of 2002 LAW AND EXPLANATION 13-17 (2002) (reprinting text and selected legislative history of Sarbanes-Oxley). 
board of directors of the issuer or to another committee of the board of directors comprised solely of directors not employed directly or indirectly by the issuer, or to the board of directors. ${ }^{54}$

Sarbanes-Oxley thus requires the SEC to adopt rules providing mandatory "reporting up" by securities lawyers. The conference committee adopted as Section 307 the Edwards amendment to the Senate bill. As Senator Edwards explained, the responsibility of corporate lawyers runs to the corporation and the shareholders. Accordingly, if lawyers "see the law being broken or about to be broken," they are supposed to "ensure that the law is being followed." Senator Edwards expressed a concern that lawyers may forget this obligation and act instead as advocate for corporate officers. He explained that Section 307 addresses this concern by requiring a lawyer with evidence of a material violation of the law to "report up" that evidence, first to the chief executive officer or chief legal counsel and then, if the violation is not addressed properly, to the board of directors. ${ }^{55}$

\section{What Went Wrong at Enron?}

What were the events at Enron that led to this reform effort? New facts continue to emerge with respect to the nature and magnitude of the Enron fraud. Among the highlights, Enron executives apparently constructed numerous sham and related party transactions in order artificially to inflate Enron's reported earnings, improperly used special purpose entities to disguise the extent of Enron's disclosed liabilities and engineered deals that generated huge payments to themselves and offered no economic benefit to the corporation. When the improprieties were revealed, the spiraling effect of Enron's restatements to its financial statements on its stock price led to the failure of additional transactions and the company's eventual collapse.

The Enron failure is remarkable not simply for the size of the apparent fraud involved, but for the universal failure of corporate gatekeepers to detect and curtail management's wrongdoing. Enron's supposedly independent board exercised minimal oversight over the company's complex financial transactions and engaged in a spectacular failure to monitor Enron executives, despite its knowledge of pervasive conflicts of interest. Enron's auditors failed to detect numerous accounting misstatements and irregularities and provided the firm with a clean bill of health. Securities analysts were unable to penetrate the house of cards and continued to tout Enron stock virtually until the company declared bankruptcy. Then there were Enron's lawyers, particularly the law firm of Vinson and Elkins

54. Sarbanes-Oxley Act, $\$ 307$ (2002).

55. See Press Release, Senate Passes Corporate Fraud Crackdown that Includes Edwards Amendment, at http://edwards.senate.gov/press/2002/0715a-pr.html; see also Letter from Edwards, supra note 49, at S5652-53 (justifying requirement that lawyers "report up" evidence of misconduct). 
("V\&E"), 56 who have been the subject of congressional hearings, named as defendants in civil suits, and the targets of extensive critical press. What precisely did the lawyers do wrong?

The alleged wrongdoing of V\&E attorneys can be divided into three discrete areas. First, V\&E lawyers assisted Enron in structuring transactions that, with the benefit of hindsight, were at a minimum aggressive and perhaps illegal. In particular, the firm issued "true sale" opinions with respect to the establishment of various special purpose entities that formed the basis for Enron's deceptive accounting. Second, V\&E drafted Enron's disclosure documents and advised Enron officials that the disclosure contained in those documents was consistent with Enron's legal obligations, when perhaps it was not. Third, after the infamous Sherron Watkins memorandum, ${ }^{57}$ V\&E conducted an investigation of Watkins's allegations, an investigation now viewed as a whitewash, and reported its conclusions to the Enron board.

The V\&E investigation is particularly troubling, because it was rife with potential conflicts of interest. V\&E apparently undertook the investigation knowing that its own lawyers were involved in structuring and approving transactions that were the subject of the investigation. ${ }^{58}$ Moreover, V\&E accepted a limited scope for the investigation that, at a minimum, constrained its ability to identify potential misconduct. ${ }^{59}$

56. Other firms that have been subject to criticism for their work related to Enron include Kirkland and Ellis and Houston-based Andrews and Kurth. See Miriam Rozen, Enron Shareholders Go After More Lawyers, Fulton CounTy Dally ReP., June 18, 2002 (discussing role of Kirkland and Ellis). But see Mary Flood, Added Lazusuits Described as Illogical; Banks and Law Firms Deny Tie-in with Enron, Houston CHron., Apr. 9, 2002, at 4 (Business) (citing Kirkland \& Ellis statement saying lawsuit contained flagrant misstatements, including on what transactions firm worked); Otis Bilodeau, New Questions Over Lawyering In Enron 'True Sale' Opinions at Issue In Probe of Controversial Deals, Legal. Times, Sept. 30, 2002, at 1 (describing role of Andrews \& Kurth in furnishing two true sale opinions with respect to Cerberus transaction).

57. See Sherron Watkins E-mail to Enron Chairman Kenneth Lay, at http:// www.itmweb.com/f012002.htm.

58. Although, even this simple fact appears subject to dispute. See Brenda Sapino Jeffreys \& Miriam Rozen, Lawmakers Grill Lawyers, NAT'L L. J., Mar. 25, 2002, at A36 (citing V\&E partner Joseph Dilg's testimony to House Committee on Energy and Commerce on March 14, 2002, that V\&E's investigation into Watkins' allegations did not involve V\&E work).

59. See James V. Grimaldi, As Enron Irregularities Mount, Outside Law Firm Subtly Tries to Deflect, and Reassign, Blame, WASH. POST, Mar. 25, 2002, at E11 (noting V\&E claims that they were not asked to review accounting); see also Financial Collapse of Enron: Hearing of the Oversight and Investigations Subcommittee of the House Committee on Energy and Commerce, 108th Cong. (2002) (statement of Representative Edward J. Markey) (comparing V\&E investigators to "Inspector Clouseau, stumbling over obvious evidence, not interviewing obvious suspects or witnesses, and, in fact, coming to conclusions that delayed the point at which a real reckoning was possible"). V\&E's attorneys are not unique in their exhibition of questionable investigatory skills in relation to recent corporate scandals. See Joseph Menn, Law Firm for Global Crossing Questioned, CHI. TRIB., Feb. 23, 2002, at 1 (Business) ("The law firm that Global Crossing Ltd. asked to examine a whistle-blower's allegations about the 
Significantly, the V\&E investigation illustrates more generally the symbiotic relationship between Enron and its counsel. By the late 1990s, Enron was V\&E's largest client, accounting for approximately seven percent of the firm's revenues. ${ }^{60}$ As a result, V\&E's revenues were heavily tied to Enron's continued financial success. In addition, V\&E maintained close personal ties to Enron. ${ }^{61}$ As many as twenty V\&E lawyers left the firm to accept jobs at Enron. ${ }^{62}$ Thus, V\&E lawyers faced inherent difficulties in subjecting the decisions and judgments of Enron officials to critical scrutiny. ${ }^{63}$

The investigation raises some of the most troubling issues of possible lawyer misconduct, but it is important to distinguish internal investigations from standard transactional work. In particular, in the context of an internal investigation, a lawyer's function more closely resembles that of an auditor. The lawyer investigator may take on special obligations; indeed, when a lawyer conducts an investigation, the client specifically relies on the lawyer to identify and report evidence of corporate wrongdoing. In addition, because an investigation is triggered by evidence of potential wrongdoing, it may not be appropriate for a lawyer to treat management decisions with the degree of deference that might otherwise be appropriate.

Although reactions to the nature of V\&E's investigation may have influenced the congressional decision to adopt Section 307, neither the statute nor the SEC rules thereunder focus specifically on the conduct of an internal investigation. As a result, although we believe that special disclosure obligations and perhaps special standards of independence may be appropriate in the context of an internal investigation, we address here the impact of the existing reforms as they affect the traditional transactional work of the securities lawyer.

company's accounting methods failed to interview the executive, the company's auditor or make sure that its board knew about the issues.").

60. See Michael C. Bender, Enron Lawyers Are Accused of Hiding Employee's Claims, Austin Am. Statesman, Mar. 15, 2002, at D1 (noting V\&E billed Enron for $\$ 36$ million over the prior year, approximately seven percent of firm revenue).

61. For example, Enron CEO Kenneth Lay and his wife invited V\&E managing partner Harry Reasoner to join a small group on a Caribbean cruise to ring in 2000. See Grimaldi, supra note 59, at E11.

62. Those V\&E attorneys included John Derrick, who became Enron's General Counsel. See Brenda Sapino Jeffreys, VEFE Closes Book on Enron, LEGAL TimEs, Mar. 11, 2002, at 16.

63. Representative Bart Stupak voiced discomfort with the relationship, noting "The closeness, the coziness of this relationship is the part that's bothering a lot of us on this committee." See Financial Collapse of Enron: Hearing of the Oversight and Investigations Subcomm. on Energy and Commerce, 108th Cong. (2002) (statement of Bart Stupak, Representative, First Congressional District of Michigan). 


\section{The Effect of Sarbanes-Oxley}

\section{A. The Value of Reporting $U p$}

Section 307 of Sarbanes-Oxley attempts to build upon the lawyer's role as information intermediary. As indicated above, the premise of the statute is not that attorneys are likely to be primary participants in corporate fraud, but rather that attorneys can effectively serve as gatekeepers. Corporate lawyers are intimately involved in investigating, structuring and disclosing corporate transactions. Through this work, they acquire a great deal of information about the company's operations and about the activities of senior management. This information may include evidence of misconduct.

A reporting up requirement seeks to modify the attorney's behavior by requiring lawyers to channel this information to top-level corporate decisionmakers. Ideally, reporting up could improve the information flow within the corporation in two ways. First, reporting up requirements may cause lawyers to investigate potential corporate misconduct more vigorously. Second, by requiring attorneys to bring evidence of misconduct to the CEO and the board, Section 307 is designed to increase the likelihood that the key corporate decisionmakers will be informed. In particular, Section 307 is designed to provide a type of early warning system for independent directors, who might otherwise, due to their limited involvement in day-to-day corporate operations, fail to identify potential problems.

Attorney reporting, as mandated by Section 307, is thus an indirect tool for improving corporate governance. The expectation of SarbanesOxley is that decisionmakers such as the CEO and the board, upon learning of corporate misconduct, will intervene to stop or prevent the wrongdoing. It is important to remember that the primary objective of the statute is to reduce fraud and other corporate wrongdoing. Accordingly, much of the value of the reporting up requirement relies on the level of response of other corporate actors.

Consequently, reporting up within the corporation is a limited vehicle for increasing corporate accountability. Indeed, as the history preceding Section 307 makes clear, the SEC and commentators have repeatedly debated whether the attorney's gatekeeping obligations should extend further. If the attorney is truly to serve as watchdog for the general good of shareholders or society, the attorney might additionally be empowered to voice his objections to corporate decisions and to force necessary corporate change. Regulatory reforms that would authorize or require attorneys to report corporate wrongdoing to regulators or require noisy withdrawals are consistent with this model. ${ }^{64}$ Similarly, attorneys' obligations could be redefined in terms of a broader social mission in which attorneys would

64. Notably, although not explicitly required to do so by Section 307 , the SEC is considering a rule that would require noisy withdrawals. See Proposed Reporting Out Rule, supra note 4. 
evaluate client conduct with reference to moral as well as legal standards. ${ }^{65}$

\section{B. Application Issues}

Notwithstanding its lofty goals, in its current form, Section 307 presents several application issues that the SEC has attempted to clarify through rulemaking. ${ }^{66}$ We do not address those application issues and instead consider the broader implications of the reporting up requirement. Nonetheless, because the scope and ambiguity of the reporting up requirement have important effects on attorney and client behavior, we identify several of the most significant problems. ${ }^{67}$

First, the scope of wrongdoing necessary to trigger the attorney's reporting obligation is unclear. Attorneys must report "evidence of a material violation of securities law or breach of fiduciary duty or similar violation by the company or any agent thereof." 68 The phrase does not specify a discrete range of misconduct, but instead references a range of conduct, both legal and illegal, that is defined by reference to both state and federal law. Importantly, because state statutory and common law development of corporate fiduciary principles varies from state to state, an attorney's reporting obligations may vary depending on the applicable jurisdiction. Similarly, in enforcing the reporting obligation, the SEC will be required to interpret and apply these state law principles. Obviously the inclusion of the term, "similar violations," renders the statute's coverage problematically vague.

Moreover, although the statute speaks to "material" violations, materiality in this context is undefined. It is unclear from Section 307 whether

65. This vision can be characterized as aspirational in the sense that nothing in the statute explicitly authorizes the SEC rules to force lawyers to make judgments about whether particular actions are contrary to shareholder or the public interest, but only whether they violate the securities laws or fiduciary standards. $C f$. Model Rule 1.13, reprinted in MORGAN \& RotUNDA, supra note 21 (setting forth conduct standard incorporating notion of acting in corporation's interest).

66. Practitioners have identified a variety of issues raised by Section 307. See, e.g., C. Evan Stewart, Holding Lawyers Accountable in the Post-Enron Feeding Frenzy, 34 SEC. Rec. \& L. RPT. (BNA) 1587 (Sept. 30, 2002); Stanley S. Arkin, Corporate Responsibility Legislation: Conflicts, Uncertainties, N.Y. L.J., Aug. 8, 2000, at 3; George W. Jones Jr., Federal Regulation of the Practice of Law: Unthinkable?, Wash. LAW., at 6 (Oct. 2002).

67. Section 307's broad wording suggests that the SEC must promulgate reporting up rules, but also has the authority to issue additional attorney rules. Some already have seized upon the language at the beginning of Section 307 to suggest that the SEC should enforce an array of ethics rules. See Remarks of Richard Painter, Symposium, Lessons from Enron . . . How Did Corporate $\mathcal{E} 2$ Securities Law Fail, 48 VILL. L. Rev. (Oct. 2002). The SEC's preliminary rulemaking efforts were far more ambitious than statutorily required. See Proposed SEC Rules, supra note 4. See also Proposed Reporting Out Rule, supra note 4. In light of these developments, it is also important to recognize the potential problems associated with SEC promulgation and enforcement of professional responsibility rules.

68. 15 U.S.C. $§ 7245$ (2002). 
the materiality standard also applies to fiduciary breaches and similar violations. Importantly, the materiality threshold may apply only to violations. The reporting up requirement appears to be triggered by any evidence of wrongdoing, without regard to the quality or quantity of that evidence.

The mechanics of reporting up are also unclear. In particular, the regulations must provide attorneys with guidance as to the nature of an "appropriate" corporate response. Will some level of corporate response short of accepting the attorney's recommendations ever be sufficient? In cases involving the exercise of professional judgment or in which reasonable minds can disagree, what sort of corporate decision-making record is sufficient to demonstrate that the attorney's information has been delivered, considered and rationally rejected? Alternatively, the statute may require attorneys to report problems all the way up to the board, unless they are resolved in the most conservative manner possible.

A final major issue is to whom Section 307's rules will apply. The statute instructs the SEC to create rules "for attorneys appearing and practicing before the Commission in any way in the representation of issuers." 69 Under this provision, the rules may focus on issuer's counsel, inhouse counsel or both. This both creates opportunities for regulatory arbitrage and insulates potential key information sources, such as underwriters' counsel, from coverage. At the same time, the application of the rules to in-house counsel is problematic in light of the limited whistleblower protection traditionally afforded to lawyers working at corporations.

\section{Would Section 307 Have Prevented Enron's Collapse?}

Regardless of how the statutory application issues are settled, it is useful to consider whether Section 307's rules would have prevented Enron's collapse. The implication of Section 307 is that the Enron failure is, at least in part, an information failure on the part of the board of directors. Section 307 suggests that lawyers act as information intermediaries and that, in some cases, lawyers may have information that would enable corporate officers or directors to prevent or remedy corporate misconduct. However, proponents of Section 307 have failed to identify the specific information that they believe Enron's attorneys, but not the board, possessed, and exactly what Enron's attorneys would have reported had the SEC rules required under Section 307 been in place. At the outset, we note that Section 307 is not tailored to the context of V\&E's internal investigation and, accordingly, we do not consider V\&E's conduct in connection with that investigation here. ${ }^{70}$

69. Id.

70. Special ethical rules may be appropriate within the context of an internal investigation because of the distinctive characteristics of the attorney's role in that context. See also James Cox, Managing and Monitoring Conflicts of Interest: Empowering the Outside Directors with Independent Counsel, 48 VILL. L. REv. (July 2003) (proposing independence standards in context of internal investigations). 
In analyzing the conduct of V\&E's lawyers, we are, of course, missing a crucial fact-whether the lawyers knew, during the course of their representation, that Enron principals were engaged in fraudulent conduct. The litigation against V\&E and other attorneys repeatedly asserts that the lawyers knowingly assisted Enron in perpetrating a fraud, ${ }^{71}$ and that may be the case, although to date, little objective evidence of such knowledge has been revealed to the public. The alternative, and perhaps more likely scenario, is that $\mathrm{V} \& \mathrm{E}$ lawyers knew of aggressive and risky transactions and reporting decisions, but did not have actual knowledge of illegal conduct.

If V\&E lawyers believed that they assisted their client in structuring and reporting on legal, albeit aggressive, transactions, ${ }^{72}$ they had no obligation to provide any information to the board under Section 307. Section 307 requires reporting up only if an attorney has evidence of a material breach of securities law or a breach of fiduciary duty. In light of the fact that the securitization transactions had been approved by Enron's auditors, it is difficult to understand how or why the attorneys should have identified a problem. More significantly, it is difficult to understand the incremental value associated with attorney reporting in light of the existing review and certification role played by the auditors.

Of course, the gatekeeper obligation can be understood more broadly than the foregoing interpretation. Indeed, some would argue that an actual knowledge standard improperly allows attorneys to shield themselves by avoiding evidence likely to reveal client wrongdoing. In other words, attorneys should have an affirmative duty to investigate and verify the legitimacy of client transactions. Whether or not such a requirement is appropriate, it is not currently part of Sarbanes-Oxley. Even in its current form, however, the statute poses the risk that hindsight bias will cause the actual knowledge standard to deteriorate, leading to attorney liability in cases in which the attorney should have known of potential wrongdoing.

Similarly, Sarbanes-Oxley does not obligate attorneys to limit their actions based on public interest or policy considerations that extend beyond the requirements of existing law. ${ }^{73}$ Section 307 would not have required

71. See, e.g., Consolidated Complaint for Violation of the Securities Laws, In re Enron Corporate Securities Litigation (S.D. Tex.) (Civil Action No. H-01-3624), available at http://www.ucop.edu/news/enron/consolidated_complaint.pdf) (last visited Feb. 27, 2003).

72. See Julie Hilden, Scummery Judgment, SLATE MAG., June 21, 2002, available at http://slate.msn.com/id/2067206/ (contrasting attorney's duties to client with accountant's duties to public and distinguishing aggressive lawyering from fraud). "The standard for fraud, however, is tough to meet and that is as it should be, for lawyers even more than other professionals. If your lawyer draws back from the edge because of her fear of the consequences, it may be you who is someday left hanging." Id.

73. Section 307 should be distinguished from regulations that broaden an issuer's obligations to disclose risky or aggressive transactions. Although attorneys are reasonably viewed as gatekeepers in the sense that they advise their clients on the required scope of disclosure, many disclosure questions involve imprecise judg- 
V\&E lawyers to remonstrate with Enron executives about the risks of the limited partnership transactions or the aggressive use of special purpose entities to make the company's financial statements appear more attractive. Section 307 only requires lawyers to "report up" evidence of wrongdoing, not evidence of uninformed, risky or inadvisable managerial decision-making.

It is, of course, possible that V\&E lawyers knew that they were assisting Enron management in the perpetration of a fraud. ${ }^{74}$ That conduct was illegal prior to the enactment of Sarbanes-Oxley and continues to be illegal. The federal securities laws prohibit lawyers from helping a client to commit fraud and, as explained above, lawyers engaging in such conduct remain subject to SEC enforcement actions seeking to impose aiding and abetting liability. ${ }^{75}$ Indeed, plaintiffs have argued that V\&E's role in drafting and approving disclosure documents renders it liable as a primary violator of Rule $10 \mathrm{~b}-5 .^{76}$ Moreover, state ethics rules currently prohibit lawyers from allowing a client to use their services to commit fraud. ${ }^{77} \mathrm{Fi}$ nally, when a lawyer for an organization assists management in self-dealing conduct, he may also be liable for malpractice. ${ }^{78}$

In light of this potential liability, it is unclear what Section 307 adds. If, in fact, V\&E lawyers were knowingly assisting Emron's management in committing fraud, it is difficult to understand why the adoption of Section 307 would cause them to report that fraud to the board of directors or anyone else. Of course, to the extent that the obligations under SarbanesOxley are limited to this context, we do not find them objectionable. Nothing in this Article should suggest that we do not believe that a lawyer who knows of corporate fraud should be required to report that fact to higher authority in the corporation. We simply argue that the regulatory reform is unlikely to effect substantial changes in the behavior of lawyers who knowingly participate in client fraud.

ments and predictions about materiality, risk and future developments. To the extent that attorney-client disagreements on those judgments generate a reporting obligation by the attorney, the statute would work a substantial change in the scope of federal securities fraud.

74. Some of the pleadings in the shareholder litigation against V\&E, however, attribute such knowledge to V\&E lawyers. See Miriam Rozen, $V \mathcal{E} E$ responds to new Enron claims, NAT'L L. J., June 24, 2002, at A25. V\&E lawyers claim that the firm played a more limited role and did not participate in broad strategic decisions. See Harry Reasoner, Misunderstanding VEFE's Role, AM. LAW., May 2002, at 15 (V\&E attorney denying that V\&E-prepared letter agreement amending loan agreement between Chewco and Jedi was "smoking gun"). Fehn).

75. See supra notes $42-44$ and accompanying text (discussing PSLRA and

76. See In re Enron Corp. Secs., Derivative \& Erisa Litig., 235 F. Supp. 2d 549, 705 (S.D. Tex. 2002) (describing V\&E's alleged "deep involvement as a primary violator in the ongoing Ponzi scheme").

77. For discussion of function of state ethics rules, see supra notes 19-26 and accompanying text.

78. For a discussion of malpractice liability as remedy for self-dealing conduct, see supra notes $27-29$ and accompanying text. 
The Enron example illustrates the reasons why, notwithstanding the increased liability exposure, there is little reason to expect that corporate lawyers will be able to improve information flow by disclosing internal misconduct to the board of directors. Either the lawyers will be unaware of the fraud, in which case they will have nothing to disclose, or they will be complicit in the fraud, in which case their interest will be in hiding the fraud, not revealing it. Moreover, a lawyer who is complicit in a fraud is already subject to sufficient liability exposure rendering the additional threat posed by Section 307 inconsequential.

One might ask, however, about the borderline case. Surely there are circumstances in which the lawyer is aware of a potential problem, but lacks actual knowledge of fraud. Perhaps Section 307 contemplates pressuring lawyers in such cases to "report up". But is such action likely or effective? Here, the business environment in which corporate lawyers operate is a key factor. Consider Enron. The lawyers at V\&E had every incentive to convince themselves that, to the extent they suspected something was amiss, they were mistaken. ${ }^{79}$ Again, Enron was V\&E's largest client, accounting for seven percent of its revenues. A substantial number of former V\&E lawyers, former friends and colleagues had become Enron employees. Enron's other advisers, including Andersen, continued to give the company a clean bill of financial health.

More to the point, what would have been the effect of reporting up? Assuming, for purposes of the discussion, that V\&E lawyers did not have actual knowledge of the fraud, what would they have told the board? They might have reported, "The company has entered into a large number of transactions with special purpose entities that appear to be consistent with the rather minimal requirements of GAAP, under an aggressive interpretation, but that dramatically reduce the amount of disclosed liabilities." The board was aware of these transactions; indeed, it approved many of them. For example, Andersen briefed Enron's audit committee on February 7, 1999-a meeting presumably more memorable because it took place in London, not Houston. At that meeting, Andersen distributed a "risk profile" chart indicating highly-structured transactions that were high risk from an accounting standpoint. ${ }^{80}$

Moreover, in advocating increased reporting to the board, it is important to distinguish the board's lack of information from after-the-fact failures of recollection. In general, the claims that the Enron board was uninformed appear overstated. Consider, for example, director Norman

79. Cf. Marleen A. O'Connor, The Enron Board: The Perils of Groupthink (working paper dated Sept. 1, 2002) (on file with authors) (describing how various psychological biases would have interfered with ability of Enron's outside directors to apprehend nature and seriousness of company's problems).

80. See The Role of the Enron Board in the Collapse of Enron Corporation: Hearing of the Permanent Investigations Subcomm. of the S. Governmental Affairs Comm., 108th Cong., (2002) [hereinafter Senate Governmental Affairs Committee Hearing] (questioning of Robert Jaedicke, Chair of Enron's audit committee, by Senator Levin). 
Blake Jr.'s claimed memory lapse about the "Osprey" transaction-an enormous transaction apparently used to support an off-the-books entity. As Senator Carl Levin explained in questioning Blake:

Now, this was a transaction where Osprey raised $a$ billion and $a$ half dollars by selling bonds to outside investors, used it to buy a stake in White Wing. Enron deconsolidated White Wing, so it took White Wing off the Enron books. . . So basically what the board did here was use Enron stock as collateral for Osprey's billion-and-a-half-dollar borrowing. ${ }^{81}$

The Osprey transaction had been referred to fifteen times in presentations to the finance committee and the board. Blake personally seconded the motion of John Duncan, former Chair of the executive committee, to approve the transaction. Yet, in response to Senator Levin's questions during Senate hearings, Blake was unable to remember the details of the transaction. ${ }^{82}$ The questioning provides a potent illustration of the failure of a director to engage in active oversight, but fails to portray Blake as the victim of an information failure. ${ }^{83}$

The lawyers also might have reported, "Enron executives have personal interests in these deals creating a potential conflict of interest." The most egregious conflicts were explicitly disclosed to and approved by the board, however. ${ }^{84}$ Despite this disclosure, the board systematically failed to monitor and investigate transactions that it knew were potentially problematic. ${ }^{85}$ On multiple occasions within a sixteen-month period, the En-

81. Id. (emphasis added).

82. See id. (noting that Senator Levin found it difficult to believe that Blake could forget approximately one and a half billion dollar transaction).

83. In addition to its role in approving specific transactions, the Enron board can be faulted for relying heavily on the judgment of others, such as Enron's management and attorneys, despite knowledge of their potential conflicts of interest. Again, the factual basis for these conflicts was well known to the board. See id.

84. In attempting to refute that LJM transactions were not vetted properly, former CEO Jeffrey Skilling testified that two large internal units reviewed the transactions-the internal accounting group and the risk control group-and that they reported directly to the audit committee of the board. See Financial Collapse of Enron: Hearing of the Oversight and Investigations Subcomm. of the House Comm. on Energy and Commerce, 108th Cong. (2002) statement of Jeffrey Skilling, former CEO, Enron Energy Corp.) (answering question from Senator Wyden). Skilling further noted, "I think we talked about the LJM structures in multiple board meetings and the process we put in place. The board of directors actually approved the structuring of the Raptors transaction ...." Id. (answering question from Senator Snowe).

85. Results from the Senate's investigation of the directors' evaluation of LJM transactions and the related waivers of Enron's code of conduct are particularly troubling. In questioning Jaedicke, Senator Levin revealed the cursory evaluation of these transactions by the corporation's audit committee. See Senate Governmental Affairs Committee Hearing, supra note 80 (Senator Levin having Jaedicke testify that committee spent no more than thirty minutes on the transactions in question). Moreover, when Fastow proposed LJM3 (and consequently needed a third waiver of Enron's code of conduct), the committee approved the waiver, but Winokur suggested that the compensation committee review Fastow's compensation and 
ron board waived the company's ethics code in order to permit Andrew Fastow, former chief financial officer of Enron, to serve as the general partner of one of the special purpose entities. ${ }^{86}$ In essence, the directors gave Fastow permission to "put his hands in the Enron candy jar." 87 The board was also informed of smaller scale conflicts, which it again approved without question. For example, in 2000 , the board approved a contract under which Enron paid over $\$ 500,000$ to a travel agency, of which Ken Lay's sister Sharon was a fifty percent owner. ${ }^{88}$

Indeed, contemplating the likely effect of reporting up at Enron leads to the inescapable conclusion that the lawyers could have had little impact on corporate policy, absent explicit disclosure of an overt fraud. Enron's directors were told time and again that the company was about to engage in high-risk transactions, but failed to react to these warnings. ${ }^{89}$ Congressional hearings revealed how the board failed to follow up on major questions. ${ }^{90}$ This was no information failure, but rather a failure of informed directors to take appropriate corporate action.

Blake suggested that the finance committee conduct quarterly reviews of the LJM transactions. The directors did not follow through with these reviews. As Senator Levin pointed out, even where directors failed to receive requested information, they took no further action:

This is the heart of the problem. You have got a board that says, I want it. You have got a request for it. It doesn't come-you do nothing. That is an approach which is unacceptable for a board. Those folks are supposed to be reporting to you. You are the captains. You make a decision. We want to find out about this compensation. You make an inquiry of an employee, and she says she doesn't have the information-she'll get back to you-she doesn't, and nothing happens. There's a Wall Street Journal article a year later. That is not the way a board can operate and carry out Id. its fiduciary duties, folk[s].

86. In describing her subcommittee's investigation of Enron and such waivers, Senator Susan Collins noted that "the subcommittee spoke with many experts on corporate governance, and not a single one had ever heard of a public company ratifying a similar proposal." Senate Governmental Affairs Committee Hearing, supra note 80 (Sen. Collins).

87. Id. (Senator Lieberman citing Enron employee Sherron Watkins).

88. See The Bitter Taste of Roast Enron, Toronto STAR, Dec. 1, 2002, at D1 (discussing role of outside directors in decisionmaking at Enron).

89. Similarly, CEO Jeffrey Skilling was warned by Jordan Mintz, General Counsel of Enron's Global Finance Unit, both about conflict of interest problems and structural problems with the Enron limited partnerships. Mintz even hired Fried, Frank, Harris, Shriver \& Jacobson to conduct an independent review on the legality of the transactions. See Tom Hamburger, Questioning the Books: Enron Had Early Warning on Partnerships, WALL ST. J., Feb. 7, 2002, at A10 (observing that Mintz began questioning procedures used to approve partnership). The limited impact of Mintz's efforts demonstrates the limitations even of conscientious efforts to "report up" potential problems.

90. For instance, in summarizing the board's handling of the LJM issue, Senator Levin explained:

The things that really trouble me in terms of the lack of real energy and effort by the board in a situation where you're using accounting methods which are clearly at the margin, high-risk; you were so informed early. 
The reason for this failure seems clear. The Enron board, although nominally independent, was subject to a number of conflicts and incentives that made it extremely unwilling to interfere with management discretion. As a result, even when the board was in possession of problematic information, it failed to act.

A number of commentators have identified conflicts, biases and relationships that may have compromised the ability of Enron directors to take appropriate action. Senator Joseph Lieberman identified ten of the fifteen most recent Enron "independent" directors as suffering from conflicts of interest. ${ }^{91}$ Enron directors had a financial and reputational stake in the company's financial success and were unlikely to do anything to jeopardize that success. Indeed, until shortly before Enron's collapse, the company was the model of new economy companies. The apparent soundness of its financial plan was reflected in its stock price. Enron directors shared in this good fortune; their compensation dramatically exceeded the normal compensation for outside directors. ${ }^{92}$ Several Enron directors had served on the board since the company's formation. ${ }^{93}$ Rob-

You know that you're using a lot of off-the-balance-sheet entities, specialpurpose entities. You're into this whole area.

You decide on a compensation review. And despite a decision in October of 2000 to do it, you don't do it. No one ever saw this initial placement memo. I take that back; your lawyer did, apparently. But your lawyer, when he saw that the conflict of interest is being touted as a reason for investors to buy LJM, apparently [wasn't] troubled by that. And if I understood you correctly, Dr. Winokur, you never asked your lawyer as to why.

See Senate Governmental Affairs Committee Hearing, supra note 80.

91. See id. (Sen. Lieberman). Such conflicts included:

contracts with Enron, common ties or contributions to charities and memberships on the boards of other companies doing business with Enron-for example, charities close to some of the directors were supported heavily by Enron and its officers. Two directors earned more than $\$ 6.5$ million in consulting fees from Enron since 1991. One director served on the board of a company that in 1999 signed a billion dollar Id. energy management agreement with an Enron affiliate.

92. See, e.g., Reed Abelson, Enron's Collapse: The Directors, N.Y. Times, Jan. 19, 2002, at $\mathrm{Cl}$ (describing average Enron director compensation in 2001 of $\$ 400,000)$; Leo E. Strine, Derivative Impact? Some Early Reflections on the Corporation Law Implications of the Enron Debacle, 57 Bus. Law. 1371, 1378, 1384 (2002) (describing estimates of outside director compensation ranging from $\$ 300,000$ to $\$ 800,000$ and citing recent survey showing average board compensation package of $\$ 138,747$ annually); see also Senate Governmental Affairs Committee Hearing, supra note 80 (Sen. Collins) (" $[\mathrm{T}]$ here is no question that Enron's board members were among the most highly compensated in the world."). Notably, stock options typically comprised much of a director's compensation package. See id. (Sen. Fitzgerald) (noting the average director got $\$ 78,000$ in cash, but $\$ 250,000$ in options). This gave directors an interest in having the value of those options increase. See id.

93. These directors included Robert Jaedicke, Robert A. Belfer and Herbert S. Winokur, Jr. 
ert Jaedicke, for example, chair of the audit committee, had been an outside director at Enron for sixteen years. ${ }^{94}$

Some Enron directors had other financial ties to the company, including consulting arrangements. Lord John Wakeham received a monthly stipend of $\$ 6,000$ for consulting services. ${ }^{95}$ Dwarfing that figure, in 2000, director John Urquhart received $\$ 493,914$ for consulting work in addition to his board compensation. ${ }^{96}$ Among those who criticized such consulting arrangements was Robert Campbell, a retired Chairman and CEO of Sunoco, who "testified that 'consulting arrangements with directors are absolutely incorrect, absolutely wrong' because directors are already paid a substantial fee to be available to management and provide their perspective on company issues." 97

Other board members had different types of financial ties to Enron. For example, Herbert S. Winokur Jr. served on the board of another firm, National Tank Company, that received millions of dollars in work from Enron. ${ }^{98}$ Director Wendy Gramm's husband, Senator Phil Gramm, received nearly $\$ 100,000$ in political contributions from Enron-related sources. ${ }^{99}$ Other directors had close ties to a medical center that had received over a million dollars from Enron and its management. ${ }^{100}$ All of these ties limited the board's independence and its willingness to scrutinize management behavior carefully. ${ }^{101}$

The board's passivity is amply documented in the Powers Report, which details the information available to the board that should have caused them to investigate. ${ }^{102}$ The board could have obtained additional information on the securitization transactions. The board had sufficient

94. See Strine, supra note 92 , at 1392.

95. See Permanent Subcommittee on Investigations of the Senate Committee on Governmental Affairs, The Role of the Board of Directors in Enron's Collapse, Rpt. 107-70, 107th Cong., 2d Sess., 55-56 (July 8, 2002) [hereinafter "Senate Board Report"].

96. See id.

97. See id. at 58 (explaining how financial ties to corporation and consultant fees can compromise directors).

98. See id. at 55-56.

99. Elaine S. Povich, Gramms and Enron: A Mutual Aid Sociely, Newsday, Feb. 10,2002 , at A6.

100. These are only some examples of the financial ties between Enron and its directors. The Senate Report on the board of directors contains additional examples. See Senate Board Report, supra note 95, at 55-56.

101. See generally id. at 5457 (finding board's independence compromised); see also O'Connor, supra note 79 (describing dangers of groupthink); of. Jared Sandberg, Six Directors Quit as WorldCom Breaks with Past, WALL St. J., Dec. 18, 2002, at A6 (noting, "[f]ew directors argued with [WorldCom's ousted CEO's] ways" when his success "made millionaires of each director many times over").

102. See William C. Powers, Jr., Raymond S. Troubh, \& Herbert S. Winokur, Jr., Report of Investigation by the Special Investigative Committee of the Board of Directors of Enron Corp., dated Feb. 1, 2002 [hereinafter "Powers Report"], available at http://www.findlaw.com; see also Senate Board Report, supra note 95 (noting array of red flags presented to the board). 
information to be concerned about the potential for insider self-dealing. The directors had access to the company's disclosure and the ability to ascertain whether its financial statements were consistent with their knowledge of the corporation's operations. Indeed, although the directors were informed of the Sherron Watkins letter in October, 2001, they never even asked to see the letter. ${ }^{103}$ Despite having extensive information that revealed potential problems at Enron, the directors repeatedly failed to act. Reporting up would not have changed that.

\section{Section 307 as a Second Best Solution}

In evaluating the propriety of Section 307, it may be unfair to focus exclusively on Enron. Perhaps the wrongdoing at Enron was too widespread and infected management at too high a level to make it amenable to the type of corporate governance solution contemplated by Section 307. Accordingly, let us look beyond Enron to examine the more general effects of Sarbanes-Oxley's reporting up requirement. In doing so, it is important to recall that corporate law delegates responsibility for corporate decision-making to the board of directors and the corporation's officers. Accordingly, the primary responsibility for preventing corporate misconduct rests with the directors and officers, not the lawyers. SarbanesOxley does not change that. In this sense, Section 307 offers a second best solution to the problem of corporate misconduct because it does not address officer or board responsibility directly. ${ }^{104}$ Instead the provision seeks to improve the flow of information to high level corporate decisionmakers by imposing disclosure obligations on attorneys. Accordingly, this section will focus upon the key issue in evaluating the statute: whether reporting up is likely to increase the quality and quantity of information available to the board and officers.

A careful cost-benefit analysis must weigh the likely effectiveness of Section 307 in improving corporate governance against the costs of implementing the statutory reforms. In particular, the analysis must consider the incentives affecting lawyer and client conduct. The incentives that drive lawyers and corporate actors raise doubts as to whether Section 307

103. Evidence in the Senate hearings revealed that by October 2001 , the board was aware of an Enron employee's anonymous letter to Kenneth Lay (which turned out to be the Watkins memorandum). Although Lay eventually reported back that there was no substance to the charges (presumably after V\&E's investigation), the board was aware that the allegations were serious enough to warrant review. Directors Jaedicke and Winokur expressly conceded, in response to questioning by Senator Collins, that they never asked to see the Watkins letter. Apparently, they eventually saw the letter as part of V\&E's written report, which was delivered in December. See Senate Governmental Affairs Committee Hearing, supra note 80 .

104. See, e.g., Richard G. Lipsey \& Kelvin Lancaster, The General Theory of Second Best, 24 REv. ECON. STud. 11 (1956) (positing that if all conditions are not optimally met, then satisfying more conditions will not likely result in resource allocation superior to that resulting if fewer conditions are fulfilled). 
will force the behavioral changes sought by its drafters. The hasty inclusion of Section 307 in the final stages of the Sarbanes-Oxley Act's drafting prevented an analysis of these factors that would have revealed the flaws in the provision's approach.

\section{A. The Market for Legal Services}

To determine the behavioral impact of reporting up rules on outside counsel, it is necessary to begin with an examination of the market for legal services in which these attorneys operate. ${ }^{105}$ Lawyers do not retain clients; clients retain lawyers. Moreover, although the corporate entity may be the lawyer's ultimate client, outside lawyers are typically hired by corporate managers and in-house counsel. Boards do not generally play a role in the retention, evaluation or compensation of outside counsel apart from special circumstances, such as counsel retained to assist an independent board committee.

As a result, lawyers face a practical situation in which, although their final allegiance runs to the corporation, their day-to-day responsibilities involve reporting to and pleasing corporate management. Management defines the objectives of the representation, identifies the responsibilities for which the lawyer has been retained and determines whether the lawyer's performance has been acceptable. Importantly, in an era in which major public companies routinely retain a number of outside firms, no lawyer's position is secure. The allocation of future work offers management a continual tool with which to reward good performance and sanction poor performance.

Compounding this issue is the importance of retaining and attracting clients to a lawyer's career. The decision to extend an offer of partnership is predicated in large part on the lawyer's ability to generate business. After being admitted to the partnership, lawyer compensation and status within the firm continue to depend on the attorney's rainmaking capacity. Other elements of the business relationship, including the desire to attract clients to a firm's law-related businesses, ${ }^{106}$ opportunities for lawyers to serve on boards of directors ${ }^{107}$ and compensation schemes in which lawyers re-

105. The significance of the market in which professionals operate is further illustrated in this volume in Jonathan Macey and Hillary Sale's evaluation of the accounting industry in light of the Enron fiasco. See Jonathan Macey \& Hillary Sale, The Demise of Professionalism in the Accounting Profession: Preliminary Observations on Commodification, Independence and Governance, 48 VILL. L. REv. (July 2003).

106. Such businesses may be the end-run around restrictions on multi-disciplinary practices. See John Gibeaut, Cash Boughs, ABA J., Feb. 2001, at 50 (explaining expansion of law firms into law-related businesses). Ironically, as law firms push into new lines of business, they may be following the same path as accountants engaged in consultancy work that undermined their credibility as auditors.

107. As recognized by the American Bar Association when it studied lawyer directors, an attorney's decision to take on the role of director introduces potential conflicts of interest. See The Lawyer-Director: Implications for Independence: Report of the Task Force on the Independent Lawyer, Section of Litigation, American Bar Association (John F.X. Peloso, Irwin H. Warren, co-chairs) (John E. Failla, 
ceive equity participation in client businesses, ${ }^{108}$ may pressure lawyers to align themselves further with management.

Competition among lawyers and law firms increases the problem. Enron's business, for example, attracted a bevy of law firms. ${ }^{109}$ If V\&EE refused to structure a transaction in accordance with management's instructions, there was a long line of competitors waiting to take its place. For smaller firms, such as Andrews and Kurth, the opportunity to attract some work from a major corporation, such as an Enron, was particularly appealing because of the visibility and credibility associated with the representation. ${ }^{110}$

Finally, the market for legal services leads lawyers to identify with their managerial clients, creating behavioral biases that limit the lawyer's ability to interpret management behavior as wrongful. Donald Langevoort has explained how the lawyer-client relationship effectively reduces the lawyer's "capacity to perceive danger signals that might indicate fraud." 11 This leads to the potential for lawyers to participate in financial fraud without a cognitive awareness of the nature and consequences of their actions. ${ }^{112}$

Understood against this market backdrop, Section 307 attempts to reduce the willingness of corporate attorneys to conceal corporate wrongdoing to placate management and to avoid jeopardizing future legal business. It is important to recognize that there are two distinct components to this process. First, the SEC rules promulgated under Section 307

reporter) (1998). Accordingly, the appropriate standards of conduct for such attorneys should be addressed separately from those applicable to other corporate attorneys. See Roberta S. Karmel, Attorneys' Securities Laws Liabilities, 27 Bus. Law. 1153,1159 (1972) (analyzing SEC complaint in National Student Marketing and noting failure to distinguish attorneys who are officers or directors from those solely serving as outside counsel).

108. See George M. Kraw, Enron Scandal Sparks Talk of Firm Conflicts, 2:7 ADvising Start-Up \& EMERging Cos. 3 (March 2002) (noting Silicon Valley attorneys demanding start ups to provide one percent or more of equity in addition to standard legal fees). Interestingly, increased equity participation by some firms in their clients' businesses may raise some of the same incentive concerns as those identified by critics of executive stock options. See, e.g., John C. Coffee, Jr., Stock for Legal Work, NAT'L L. J., Jan. 8, 2001, at B5 (noting possible conflicts from payment by stock); see also Lucian Arye Bebchuk, Jesse M. Fried, \& David I. Walker, Managerial Power and Rent Extraction in the Design of Executive Compensation, 69 U. CH. L. REv. 751, 837-41 (2002) (examining ability of managers to extract rents and influence their compensation packages).

109. See Nancy Dunne, Enron Lawyers: 'We Proceeded in Good Faith', Fin. Times, Mar. 15, 2002, at 7 (V\&E partner Dilg describing V\&E as "only one of hundreds of law firms" used by Enron).

110. See Brenda Sapino Jeffreys, VEFE Closes Book on Enron, Legal Times, Mar. 11,2002 , at 16 (noting prior to its bankruptcy, Enron was largest client of Bracewell and Andrews \& Kurth). A few major corporate clients can occupy a smaller firm's attorneys for extended periods of time.

111. Donald C. Langevoort, Where Were the Lawyers? A Behavioral Inquiry into Lawyers' Responsibility for Clients' Fraud, 46 Vand. L. Rev. 75, 95 (1993).

112. See id. (examining lawyer complicity in client wrongdoing). 
specify appropriate standards of conduct for corporate counsel. Second, and perhaps more importantly, lawyers who deviate from those standards of conduct will be subject to liability. The SEC is already empowered to proceed against lawyers who violate SEC rules, either in the form of a disciplinary proceeding or through an enforcement action in federal court. Section 602 of Sarbanes-Oxley both codifies the SEC's disciplinary authority under Rule 102(e) of the Commission's Rules of Practice and perhaps lowers the applicable standards for the exercise of that authority by providing that a single instance of negligent conduct can justify SEC sanctions. ${ }^{113}$

It is, therefore, important to understand Section 307 as extending beyond aspirational standards or guidelines. Inserting a reporting up requirement into the federal securities laws subjects the corporate lawyer who fails to adhere to that requirement to a meaningful risk of enforcement liability. ${ }^{114}$ Thus, Sarbanes-Oxley is intended to increase the lawyer's concern with his own legal exposure in order to reduce his willingness to assist clients in the commission of wrongdoing. In economic terms, the lawyer's financial incentive to obtain and retain clients will be counterbalanced by the increased risk of liability. If, prior to Enron, lawyers faced limited liability exposure because of the limitations on private civil litigation and the SEC's minimal enforcement efforts, the new rules may alter the equation. ${ }^{115}$

Nonetheless, under Section 307, as under prior law, a lawyer's decision to go to the CEO or the board over management's head is a serious one. In many corporations, the decision is likely to jeopardize the lawyer's future relationship with that client. If the board has chosen the manage-

113. Compare the comments of former SEC Commissioner Norman Johnson, "My view is that Carter \& Johnson viewed the practice of law as to allow even negligence, as necessary to accomplish the Commission's larger purposes." Remarks of Commissioner Norman S. Johnson to the American Bar Association Federal Securities Law Committee, Suits Against Lawyers, The Mayflower Hotel, Washington, D.C., Nov. 8, 1996 (citing Carter and Johnson in finding that "[I]f a securities lawyer is to bring his best independent judgment to bear on a disclosure problem, he must have the freedom to make innocent-or even, in certain cases, careless mistakes without fear of legal liability or loss of the ability to practice before the Commission.").

114. Although the statute purportedly does not create a private right of action, a lawyer's existing liability exposure for malpractice and similar claims may be influenced by the extent to which the new rules are viewed as professional standards of conduct.

115. It is not clear that this alteration is desirable. To the extent that the lawyer's concern for his own liability is increased, this shift comes at the cost of a reduced concern for his client's interests. As the SEC noted in Carter and Johnson, "Concern about his own liability may alter the balance of his judgment in one direction as surely as an unseemly obeisance to the wishes of his client can do in the other. While one imbalance results in disclosure rather than concealment, neither is, in the end, truly in the public interest." In re William R. Carter \& Charles J. Johnson, Jr., [1981 Transfer Binder] Fed. Sec. L. Rep. (CCH) If 82, 847, 1981 SEC LEXIS $1940, * 81$ (1981). 
ment team and has confidence in management, reporting up may place the board in the untenable position of taking sides between its trusted executives and an outside lawyer. As a consequence, a lawyer's unproven suspicions, particularly when those suspicions do not rise to the level of tangible proof of fraud, are more likely to hurt the lawyer than management. Similarly, reporting up, especially in circumstances in which the lawyer's concerns do not result in the detection and termination of corporate wrongdoing, may compromise a lawyer's professional reputation. Other managers will be unwilling to hire a lawyer who is known as a whistleblower. Managers may reasonably be concerned about the lack of trust evidenced by the lawyer's behavior and the resulting effect on the quality of representation. Because Section 307 does nothing to address directly the factors that pressure lawyers engaged in the market for legal services, the ability of increased liability to change behavior substantially is far from certain.

\section{B. The Effect of Section 307 on Lawyer and Client Incentives}

In the context of this market environment, what will be the effect of Section 307? For those attorneys actually motivated by Section 307's liability standards, we suggest that one possible response is over-reporting. If the scope of the reporting obligation is unclear or ambiguous and lawyers face a meaningful risk of liability if they fail to report, it becomes rational for lawyers to report all possible information related to actual, likely or even improbable wrongdoing to the board. Over-reporting is a viable solution to the lawyer's dilemma for two reasons. First, a lawyer who constantly reports up minimizes his liability exposure under Section 307. Second, as the frequency of reporting increases and the significance of the reported issues decreases, the signaling effect of reporting up changes. Reporting up becomes a ritualized procedure rather than demonstrating a lack of confidence in management. This enables a lawyer to achieve superficial compliance with the statute while maintaining his relationship with management.

Over-disclosure is consistent with existing operational practices of corporate attorneys. Corporate attorneys regularly attempt to draft broad disclosure statements that limit potential client liability for failure to disclose. One can similarly envision such attorneys drafting and submitting memoranda to the board with boilerplate language warning of potential wrongdoing. Given the vague standards contained in Section 307, such a response could be rational. It is unclear how an outside attorney ever would have enough information to determine definitively that any possible impropriety has no chance of being "material"116 or that "appropriate" action had been taken to remedy corporate wrongs.

116. The statutory qualifiers of materiality and possible cure by appropriate action offer limited protection to a risk averse lawyer. The likelihood of having 
The obvious effect of over-reporting is to reduce the qualitative significance of reporting up. Although boards would receive a greater quantity of information, that information would not meaningfully improve their ability to identify and respond to corporate wrongdoing. Section 307 may simply lead to a practice of broad and essentially meaningless disclosure of all known business risks. The result would be a classic "noise" problemtoo much information to be processed by the recipients.

The quality of attorney speech should not be confused with the quantity of such speech. Almost a century ago, in his exposition on the ethical obligations of attorneys, Suffolk School of Law Dean Gleason L. Archer warned of "the evils of too much advice" and characterized clarity and intelligibility of advice as a "duty" of the attorney. ${ }^{117}$ To the extent that Enron identifies a need for directors to receive more meaningful warnings of potential problems from counsel, broad-based disclosure of all known legal and business risks does not provide those warnings.

In addition to prompting over-disclosure, Section 307 also may reduce the attorney's incentive to become fully informed about the client's business. An attorney only will be accountable for the failure to disclose information that he knows. Section 307 does not create a "should have known" standard that would mitigate the incentive to ignore corporate malfeasance. ${ }^{118}$ Accordingly, an attorney can limit his liability under the statute by not seeking evidence of legal or fiduciary impropriety. Mandatory reporting up could thus motivate attorneys to turn a blind eye to corporate problems. More generally, by reducing lawyers' incentives to increase their understanding of the client's business, the statute may reduce their effectiveness as counselors.

Section 307 also will affect the incentives of corporate management. Managers operate under the supervision of the CEO and the board of directors. Managers will seek to minimize the likelihood that their activities will be critically assessed through the reporting up process. No man-

one's conduct reviewed with $20 / 20$ hindsight counsels in favor of resolving all close calls in favor of disclosure.

117. Gleason L. Archer, Ethical Obligations of the Lawyer 88-90 (1910).

118. We do not endorse such a standard given our more general objections to the statutory scheme, but emphasize the failure to include such a standard is indicative of a gap in the proposed regulatory scheme. The difficulty of filling such a gap is illustrated by attempts in the Commission's initially proposed rules to introduce a reasonableness standard into the definition of evidence of a material violation that is not required by Section 307. Under the proposal, "[e]vidence of a material violation means information that would lead an attorney reasonably to believe that a material violation has occurred, is occurring, or is about to occur. See Proposed SEC Rules, supra note 4 . Ostensibly, the Commission offers the standard "to preclude reports based on mere suspicion of material violation." Id. However, such language might be read to extend attorney reporting requirements to evidence of which the attorney has no knowledge. See Comment Letter of Susan P. Koniak, et al. to Jonathan G. Katz, File No. 33-8150, at 2 (Dec. 17, 2002) http:// www.sec.gov/rules/proposed/s74502/skoniak1.htm (identifying "reasonably believes" standard as most important concern in proposed rules). 
ager will rationally welcome being subjected to the type of scrutiny contemplated by Section 307.

Although one potential consequence will be a reduction in overall levels of corporate misconduct, an alternative will be greater efforts by corporate managers to minimize attorney knowledge of corporate operations. ${ }^{119}$ If information flow to attorneys has the potential to produce reporting up obligations, those obligations can be reduced by minimizing information flow from the issuer to the attorneys.

A reporting up obligation creates a wedge between the lawyer and executives with whom the lawyer is engaged. The SEC recognized this problem in Carter and Johnson, observing, "Lawyers who are seen by their clients as being motivated by fears for their personal liability will not be consulted on difficult issues." 120 Nor will clients be willing to share information with their attorneys if they fear the attorneys will second-guess them. This is particularly discomforting since corporate actors have an informational advantage over attorneys. In a corporate attorney-client relationship, the most basic information failures involve the flow of information from the client to the attorney, not in the opposite direction as suggested by the statute. It is essential to remember that corporate attorneys do not have, nor does the statute give them, the powers of an inspector general. An attorney's understanding of the corporation's operations and problems will be determined by the willingness of corporate employees to provide that attorney with information.

The quality of the attorney's counsel is a function of the quality of information he receives from the client. The need for attorneys to act on an informed basis is at the heart of one of the bar's most valued ethical principles-the attorney-client privilege. In Upjohn Co. v. United States, ${ }^{121}$ the Supreme Court explicitly recognized the importance of open dialogue between corporate actors and counsel in extending the privilege to the corporate context. This objective of full and frank communication is undermined if attorneys are statutorily required to second-guess the appropriateness of those actors' responses to corporate problems.

In addition to reducing the likely flow of information from managers to attorneys, Section 307 is likely to impede attorney effectiveness in other ways. An informed attorney who enjoys a relationship of trust and confidence is best situated to influence the corporation's behavior. This is a further reason for applying the attorney-client privilege to communications between corporate executives and the corporation's lawyers. A close

119. In responding to Enron and public misunderstanding of the lawyer's role, one attorney explained, "They assume that lawyers operate in a larger universe than they often do." The attorney added that "lawyers often lack any basis of knowledge to evaluate client's larger purposes or strategies." See Anthony Lin, Law Firms Concerned Over Enron's Impact, N.Y. L.J., Mar. 15, 2002, at 1.

120. In re William R. Carter \& Charles J. Johnson, Jr., [1981 Transfer Binder] Fed. Sec. L. Rep. (CCH) I 82, 847, 1981 SEC LEXIS 1940, *81 (1981).

121. 449 U.S. 383 (1981). 
relationship and dialogue between outside counsel and a corporation's managers need not be nefarious or indicative of "capture" by management of that attorney. Rather, a close relationship between managers and lawyers should maximize the effectiveness of corporate decision-making. Indeed, a zone of privacy between corporate decisionmakers and their lawyers encourages self-policing within the corporation and increases a corporation's ability to conform its actions to the law. ${ }^{122}$

Moreover, another aspect of the corporate attorney-client relationship should not be ignored. Corporate lawyers are frequently asked for opinions that reflect a combination of business and even moral judgments that go beyond legal advice. ${ }^{123}$ Sometimes the attorney's business judgment may conflict with the course ultimately chosen by management, although management's preferred course is entirely legal. Prior to Sarbanes-Oxley, the attorney had to decide when such disagreements should be reported up. In making that decision, the attorney presumably weighed his role as an agent for the corporation, his professional responsibility obligations under legal ethics rules, his knowledge of potential aiding and abetting or malpractice liability should management's actions actually be illegal despite the attorney's judgment to the contrary and, perhaps most importantly, his understanding that his central role was as a legal, not a business, advisor.

Without carefully considering the attorney's proper role, the statute effectively converts the attorney's business judgments into legal judgments. Faced with the broad liability standards of Section 307, the conservative attorney might reasonably choose to "report up" these differences in business judgment out of fear that they might be perceived at a later time as legal improprieties. Managers who feel they are being constantly second-guessed might ultimately hire new legal counsel, less familiar with the corporation, further undermining the quality of representation.

Finally, Section 307 may create a type of moral hazard problem for corporate decisionmakers. Corporate law charges the board of directors with the responsibility of corporate oversight. Toward that end, corporate directors are statutorily empowered to demand the information necessary to monitor corporate decision-making. The structure of the board, including director independence requirements, is also designed to facilitate independent oversight. By obligating lawyers to report information rather

122. See Fred D. Baldwin, Conflicting Interests 127-29 (1984) (discussing social value of privacy).

123. See James A. Cohen, Lawyer Role, Agency Law, and the Characterization "Officer of the Court," 48 Bufr. L. Rev. 349, 406 (2000) (observing that, while lawyer's "duty of candor allows the lawyer to discuss the matter broadly, exploring options from many perspectives ... it does not permit the imposition of the lawyer's values or moral on the client."); $c f$. Richard W. Painter, The Moral Interdependence of Corporate Lawyers and Their Clients, 67 S. CAL. L. REv. 507 (1994) (analyzing influence of moral independence theory on lawyer's responsibility for client's conduct). 
than obligating directors to demand information, Sarbanes-Oxley encourages directors to reduce their information-seeking efforts and to blame information deficiencies on the failure of outside professionals. Indeed, the congressional hearings on Enron are rampant with directors' efforts to pass the buck to their professional advisers rather than accepting responsibility for understanding the nature and the risks of Enron's businesses practices. ${ }^{124}$

\section{Summary of Benefits and Costs}

In summary, an analysis of the benefits and costs of Section 307 suggests that its approach is misguided. In terms of benefits, the statute is unlikely to cause lawyers to operate as effective information intermediaries. The statute does not reduce the central importance of client retention decisions in the market for legal services. As a result, increasing the risk of attorney liability is unlikely to generate greater attorney resistance to client demands. Instead, attorneys will be driven to avoid obtaining evidence of securities law violations and fiduciary breaches and to over-report instead of providing high quality guidance to officers and directors. Moreover, the costs of Section 307 are substantial. The statute is likely to cause corporate actors to reduce information flow to their attorneys, to curtail the attorney-client dialogue and to rationalize further their own inaction in addressing corporate problems. ${ }^{125}$ Ultimately, the statute may sacrifice quality representation in favor of routinized disclosures.

It is important to place the gatekeeping function of Section 307 within the context of the attorney's role in structuring corporate transactions. As Jack Coffee explains, the professional gatekeeper is an independent reputation intermediary "who provide[s] verification and certification services to investors." 126 A gatekeeper's reliability is based, in part, on the gatekeeper's independence from the transactions that it certifies. ${ }^{127}$ Lawyers, on the other hand, traditionally serve as transaction engineers. Because the lawyer assists the client in structuring the very deals that the lawyer would then attempt to evaluate from a compliance perspective, the lawyer lacks sufficient independence to serve as a viable gate-

124. See Senate Governmental Affairs Committee Hearing, supra note 80 (recounting directors' claims of ignorance or reliance on outside professionals); Senate Board Report, supra note 95 (same); see also Powers Report, supra note 102 (same).

125. The SEC's initial proposed rules went beyond Section 307's requirements and effectively extended attorney reporting outside the corporation. For example, the proposed rules required attorneys under some circumstances to disavow affirmatively client filings submitted to the Commission. See Proposed SEC Rules, supra note 4 . If they are adopted, such rules likely would exacerbate the concerns this Article raises about damage to the attorney-client dialogue.

126. John C. Coffee, Jr., Understanding Enron: "It's About the Gatekeepers, Stupid", 57 Bus. Law. 1403, 1405 (2002).

127. Ironically, other provisions found in Sarbanes-Oxley seek to prevent accountants from serving this dual function of auditor and consultant. 
keeper. ${ }^{128}$ Indeed, the point is illustrated by the failure of V\&E's efforts to investigate Sherron Watkins' allegations. Having played a key role in structuring related deals, V\&E was structurally incapable of evaluating the legality of those deals objectively.

\section{A Demand Side Approach to Reform}

This Article argues that the failures of Section 307 stem from the fact that it is a second best solution. The provision looks to private service providers from outside of the organization to transform corporate governance. Imposing independent gatekeeper obligations on attorneys is inconsistent with the incentives imposed by the market for legal services. Faced with such a conflict, attorneys must sacrifice gatekeeper obligations to client accountability. This does not lead to the conclusion that improved information flow between attorneys and corporate clients is either unnecessary or inappropriate. Indeed, we share Congress's conclusion that greater information flow would benefit the corporation and its shareholders, although we disagree on the appropriate mechanism for increasing information flow. In the light of the relevant incentives for attorneys and other corporate actors, as well as the asymmetries of information and power between these critical players in the corporation's activities, we argue that the solution to the information problem should be a demand side solution. Regulatory reform should increase the incentives for corporate decisionmakers to demand information from their lawyers. By aligning the interests of attorneys and corporate actors, a demand side solution will prevent market incentives from undermining the reporting process.

Responsibility for corporate decision-making is vested in the board and senior corporate officers. The corporation's directors and officers have the legal authority to set corporate policy, make corporate decisions and monitor the decisions of lower level corporate employees. ${ }^{129}$ As Senator Carl Levin explained:

One of the key players responsible for overseeing the operations of publicly held corporations is the board of directors. Directors are charged by law to be the fiduciaries, the trustees, who protect the interests of the corporate shareholders. In that capacity, they're supposed to exercise their best business judgment on behalf of those shareholders. They're supposed to be independent.

128. As a practical matter, the corporate attorney need not play both the role of transaction engineer and final auditor. Corporate law recognizes the right of a board or audit committee to retain separate counsel where necessary or appropriate. See, e.g., Sarbanes-Oxley Act, $\$ 301$ (2002). Clearly, the investigation of the Watkins memorandum was a time where retention of independent counsel would have been appropriate and wise. The demand based alternative to corporate governance reform that we offer below would create incentives for more active board oversight and provide a structural mechanism by which such retention can occur. 129. See generally Robert Charles Clark, Corporate Law (1986) (describing standard hierarchical corporate management structure). 
And while they're not expected to be detectives, they are expected to ask tough questions of management, to probe opaque answers, and to display sufficient skill and fortitude to say no to transactions that don't look right. ${ }^{130}$

Unfortunately, a common factor in many of the recent corporate scandals was a lack of adequate supervision by officers and directors. ${ }^{131}$ Thus, "first best" solutions should focus on the heart of corporate governance-those directors ${ }^{132}$ and officers. More specifically, regulations should provide incentives to directors and officers to seek and take good legal advice. We provide several possibilities below for creating such incentives.

\section{A. Certifications}

Requiring additional personal certifications of the contents of corporate communications and reports could focus corporate decisionmakers on ensuring the accuracy of such documents as well as the quality of professional advice used in their preparation. The reaction of corporate actors to recent SEC requirements for the certification of financial statements by chief executive officers and chief financial officers ${ }^{133}$ indicates the potential motivating power of such requirements. Initially, it was unclear what these rules added to the reporting system. After all, even before their adoption, corporations were not legally permitted to distribute inaccurate financial statements. ${ }^{134}$

One possible explanation for the requirement was as a symbolic gesture to restore investor confidence quickly. However, official response to the requirement was quite different. Rather than immediately certifying

130. Carl Levin, Senate Governmental Affairs Committee Hearing, supra note 80.

131. See, e.g., Did Tyco Board Know About Pay?: Meeting Minutes Reportedly Show Loans Were Discussed, REUTERs, Sept. 23, 2002, available at http://www.msnbc.com/ news/811710.asp?0dm=C13MB (citing New York Times report that minutes of board's compensation committee showed that it knew of problematic compensation payments many months before board took steps to disclose them).

132. Others have joined the United States in refocusing on the role of directors and corporate governance in the wake of Enron's collapse. Notably, in the United Kingdom, reformers have focused on reinvigorating non-executive directors, who must be willing to take action, including resignation on principle, to effect corporate change. See Tony Tassell, Call for More Boardroom Whistleblowers, Fin. Times, Aug. 30, 2002, at 2; see also Letter from Clare Gaudet, Senior Vice President Issuer Services, Toronto Stock Exchange, to Denise Houde, Ogilvy Renault Law Firm (Apr. 29, 2002) (describing Exchange's issuance of corporate governance guidelines focusing on board responsibilities).

133. See Order Requiring the Filing of Sworn Statements Pursuant to Section 21 (a) (1) of the Securities Exchange Act of 1934, File No. 4-460 (June 27, 2002), available at http://www.sec.gov/rules/other/4-460.htm (last checked Feb. 3, 2002).

134. See Jonathan Weil, Is Aug. 14 Filing Deadline a Nonevent?, WALL St. J., Aug. 13,2002 , at C1 ("Under the old way of doing things, corporate executives were supposed to tell the truth to the public in their financial filings, and their companies' financial statements had to comply with generally accepted accounting principles. The main difference now is that they will have to swear to that."). 
their financial statements, most corporate officials waited until close to the regulatory deadline, taking the maximum amount of time to investigate and review the documentation and consulting with their professional advisors in order to ensure that the financial statements were in order. ${ }^{135}$ In other words, officials appeared to take the certification process and the risk of personal liability seriously. As a result, the requirement appears to have generated an increased focus by corporate officials on the quality of corporate disclosure. ${ }^{136}$

\section{B. Increased Liability Exposure for Directors}

In addition to certifications, increased risk of liability certainly would refocus directors. In particular, if courts imposed on directors a meaningful obligation to become informed and held directors accountable when they failed fully to understand corporate transactions, directors would demand better information and legal advice on the corporation's operations. How to augment directors' liability exposure is a complex task beyond the scope of this Article. Items to consider would include the actual duties of directors, ${ }^{137}$ the vehicles for enforcing those duties ${ }^{138}$ and

135. See Michael Schroeder, Under Gun from SEC, Bristol, Others Divulge Accounting Issues, WALL ST. J., Aug. 15, 2002, at Al (describing "mad deadline rush" for filers). Stephen Crimmins of Pepper Hamilton observed, "It's fair to say that all lawyers who practice in the area of securities regulation spent the better part of the last week or two fielding questions from clients relating to the new certification requirement." Id. See also U.S. Securities and Exchange Commission, Statements by Company CEOs and CFOs, at http://www.sec.gov/rules/extra/ceocfo.htm (providing dates officer certification statements were received).

136. Recently, Charles Schwab, Chairman and Co-CEO of Charles Schwab Corp., proffered certification as a governance tool for the financial services industry. He proposed requiring every CEO and chief compliance officer of a financial services firm to certify that controls were in place to protect investors from conflicts of interest and to describe how those controls work. See Charles R. Schwab, Remaking the Market: My Investors, My Responsibility, WALL St. J., Nov. 5, 2002, at A22. Certifications by key corporate actors at a broader range of companies might focus those actors on how internal controls work, as opposed to merely relying on those controls to rationalize their failures to detect misconduct. Cf., Financial Collapse of Enron: Subcomm. on Oversight and Investigations of House Energy and Commerce Comm., 108th Cong. (2002) (testimony of Robert Jaedicke, Chairman, Enron Audit and Compliance Committee) (claiming directors' entitlement to rely on internal controls).

137. See generally Edward M. Joffe, The Outside Director: Standards of Care Under the Securities Laws, 24 EMORY L.J. 669 (1975) (examining duties of outside directors in registration of securities, purchase or sale of securities and solicitation of proxies).

138. The SEC has yet to bring an enforcement action against outside directors in connection with a corporation's disclosure violations. Even after Enron, the SEC's appetite for such cases is unclear. See Scot J. Paltrow, SEC Isn't Likely to Discipline Enron Board, WALL ST. J., Sept. 25, 2002, at C1 (quoting Linda C. Thomsen, Deputy Enforcement Director as explaining that outside directors are "'so removed from the day-to-day operations that proving their involvement and their intent and their state of mind becomes more difficult.'”); $c f$. Associated Press, SEC Will Discipline Culpable Directors, WALL ST. J., Sept. 26, 2002, at C3 (citing enforcement director Stephen Cutler's willingness to consider actions against directors). 
whether director and officer liability insurance policies create issues of moral hazard for covered individuals. ${ }^{139}$

Liability exposure for outside directors is particularly significant. Such directors are key to the "monitoring board" model of corporate governance. Recent empirical research by Sanjai Bhagat and Bernard Black calls into question whether such directors actually are making a difference. $^{140}$ It does not follow, however, that outside directors cannot play a significant role. As Bhagat and Black themselves acknowledge in discussing the policy implications of their research findings, perhaps the problem is that the independent directors are not nearly as independent as previously thought and need additional incentives. ${ }^{141}$ Their findings are consistent with anecdotal evidence of independent directors who sit on multiple boards, collect fees, but rarely review corporate materials. Indeed, many years before Enron, some outside directors were viewed as "conduits of management who affirm without question actions planned and administered by others." 142 Although higher standards of conduct for outside directors may reduce director willingness to serve, in light of the importance of board monitoring, this may be a desirable result.

Similarly, although not appropriate in every case, the threat of criminal liability is likely to increase the incentives of corporate executives to take a more active role in identifying and limiting corporate wrongdoing. Criminal prosecution provides highly visible evidence that corporate misconduct is inconsistent with societal standards and that illegal conduct does not constitute accepted business practice. Moreover, select criminal prosecutions can dramatically deter wrongdoing. The prosecutions of Ivan Boesky and Michael Milken appeared to effect substantial changes in the climate and practices on Wall Street. ${ }^{143}$ More recently, the psychological impact of seeing corporate executives taken away in handcuffs may prove to have a similar effect.

139. See William Cotter \& Christopher Barbee, 2002 D\&O Insurance WhITE PAPER (2002) (addressing current and future scope of Directors and Officers insurance coverage).

140. See Sanjai Bhagat and Bernard Black, The Non-Correlation Between Board Independence and Long Term Firm Performance, 27 Iowa J. CoRP. L. 231 (2001) (finding firms with more independent directors do not perform better than other firms).

141. See id. at $266-67$ (questioning true extent of director independence).

142. Joffe, supra note 137, at 669 (1975).

143. In sentencing Boesky, the court emphasized the purpose of general deterrence. See Boesky Sentenced to Three Years, Judge Stresses General Deterrence, 19 SEc. ReG. \& L. RPT. (BNA) 1951, Dec. 25, 1987. 


\section{Internal Legal Controls and Legal Audit Committees}

Deterrence should not be the only focus of demand side reforms. ${ }^{144}$ Empowerment of honest directors and officers is also important. In the current environment, this notion may seem indisputable, but previously it has drawn controversy. Notably, former U.S. Supreme Court Associate Justice Arthur J. Goldberg resigned from TWA's board of directors after he concluded that he had inadequate access to corporate information, and his entreaties for separate technical advisers that answered directly to the board failed. ${ }^{145} \mathrm{~A}$ board's access to independent legal advice can make a difference.

Former Commerce Secretary Peter Peterson made this point during a recent panel discussion on corporate governance. ${ }^{146}$ In describing his own experiences as a director for several boards, Peterson emphasized the interplay between attorneys and directors in addressing corporate problems. He explained that on more than one occasion a corporation initially used its regular outside counsel to investigate problems. When Peterson pushed the corporation to secure independent outside counsel, however, that counsel discovered problems that the other attorneys failed to detect. Directors, such as Secretary Peterson, who are willing and able to demand appropriate advice are far more likely to detect corporate problems and to force real solutions. ${ }^{147}$

One method of increasing information flow to corporate decisionmakers is the development of information reporting systems relating to legal representation. Some corporations already provide structures through which the general counsel, the board or the CEO demands information from inside and outside counsel on a regular basis. Systems through which lawyers are regularly required to provide information on

144. See Tom R. Tyler, Trust and Law Abidingness: A Proactive Model of Social Regulation, 81 B.U. L. REv. 361, 396-98 (2001) (noting limits of deterrence in securing legal compliance).

145. See BALdwIN, supra note 122, at 137-39. In the past, concerns centered on creating "divisiveness and friction while blurring line of responsibility. As Professor Melvin Eisenberg put it, 'It would create a shadow staff with an institutionalized obligation to second-guess the management, but with very limited responsibility for results." Id. at 137-38. Even in more recent times skepticism remains about permanent staffs for directors. See Albert A. DeStefano Lecture on Corporate Securities $\mathcal{G}^{2}$ Financial Law, Panel Discussion: Enron: What Went Wrong?, 8 Fordham J. Corp. \& Fin. L. S1, S43-S44 (2002) (Daniel V. Dooley, Partner, PricewaterhouseCoopers LLP, calling for audit committee staff).

146. See International Symposium on Risk Management and Derivatives, Focus on Corporate Governance, Director and Officer Responsibility: A Plan for Action, Panel 2, Corporate Governance Issues, 8 Fordham J. CoRP. \& FIn. L. 49, 78 (2003).

147. Indeed, the drafters of Sarbanes-Oxley recognized the significance of access to counsel in permitting audit committees to secure such counsel. See Sarbanes-Oxley Act, $\$ 301$ (2002) (amending Section 10A of Securities Exchange Act of 1934, 15 U.S.C. 78f, by adding new paragraph $(\mathrm{m})(5))$. Interestingly, in the statute's final balance, the audit committee's use of counsel is voluntary and subject to the directors' judgment while attorney reporting is mandatory. 
risks, liabilities and other potential problems relieve the lawyer of the responsibility for coming forward with information about potential misconduct. Structures in which lawyers regularly report directly to the board or a key corporate official allow lawyers to bypass managers without creating the risk of retaliation that might result from sporadic reporting up. Moreover, reporting structures signal to outside lawyers the corporation's receptiveness to such information and reduce the perceived risk of client displeasure. If corporations were required to institute such reporting systems as part of their system of internal controls, information flow would be both increased and regularized. In addition, because they would be responsible both for instituting the systems and ensuring that they were reliable, corporate decisionmakers would have an incentive to reward lawyers for high quality reporting. ${ }^{148}$

A more formal mechanism for empowering directors to obtain legal advice is the establishment of a legal audit committee. ${ }^{149}$ A committee whose mission is to ensure legal compliance could focus on the quality of the corporation's legal resources and could demand that the corporation's lawyers, both in-house and outside counsel, thoroughly inform directors and officers as they make corporate policy. Such a committee could provide an additional mechanism for regular information flow between the board and the lawyers. Consistent with recommendations for improved corporate governance following Enron's collapse, ${ }^{150}$ the committee could meet without management present, fostering freer discussion among its members and counsel to the corporation. Moreover, such com-

148. Criminal sanctions, as regulated by the U.S. Sentencing Guidelines can reinforce such systems. Under the Guidelines, organizations sentenced for wrongdoing are given credit for having "an effective program to prevent and detect violations of law." See United States Sentencing Commission, Guidelines Manual, $\S 8 \mathrm{C} 2.5(\mathrm{f})$ (Nov. 2002). By definition, to be "an effective program," the compliance efforts must include "a reporting system whereby employees and other agents could report criminal conduct by others within the organization without fear of retribution." USSC $\$ 8 A 1.2$, comment $(\mathrm{n} .3(\mathrm{k})(5))$.

149. Others have recognized the potential usefulness of separate committees. Fred Baldwin alluded to such committees in discussing the debates arising in the environment following Watergate and Justice Goldberg's TWA resignation. See BALDWIN, supra note 122. More specifically, in addressing an ABA proposal to force in-house counsel to seek further consideration of actions that would harm the corporation, Baldwin noted, "Naturally, attorneys may not be willing to do these things and may not even be sensitive to the issues involved. Boards may find it necessary to establish special committees (for example, the ethics or public-policy committees) and provide that one of their functions is to listen to legal warnings that management seems to be ignoring or underestimating." Id.

150. See, e.g., New York Stock Exchange Corporate Accountability and Listing Standards Committee, Report 9 (June 6, 2002) (recommending that "non-management directors of each company must meet at regularly scheduled executive sessions without management" to empower them to serve as better check on management). 
mittees could involve directors more directly in the retention, evaluation and compensation of corporate counsel. ${ }^{151}$

Legal audit committees also offer a venue to deal with different lawyers hired by the corporation to serve different roles. For example, such committees can focus on the special issues raised by using lawyers in the capacity of corporate investigators. More generally, a standing committee offers a ready mechanism for obtaining legal counsel in order to deal with potential conflicts of interest. ${ }^{152}$

\section{Conclusion}

The benefit of increasing information flow within the corporation in order to increase the ability of directors and officers to discover and address corporate wrongdoing is incontıovertible. However, this proposition alone does not support Section 307's approach to corporate governance reform. In particular, this Article has argued that attorneys are poorly positioned to serve as information intermediaries. Moreover, efforts to improve information flows through SEC rules that mandate reporting up and sanction lawyers for failure to comply are likely to be counterproductive.

We do not suggest that attorneys should refuse to alert their corporate clients about wrongdoing. The requirement that they do so is already recognized in traditional attorney professional responsibility standards and securities anti-fraud provisions that remain viable after Central Bank. It is not the purpose of this Article to judge V\&E's guilt or innocence on incomplete facts, but if V\&E lawyers aided and abetted fraud, they can be held accountable under existing legal standards.

Enron also may highlight an overdue obligation by attorneys to clean their own house. Enron only rekindled earlier questions about the effectiveness of attorney self-discipline. ${ }^{153}$ Bars and states must enforce diligently their own ethics rules and adjust those rules to address concerns arising out of the current crisis. If attorneys do not act, more draconian measures may follow, including requirements that require direct reporting to the government authorities. ${ }^{154}$ Indeed, in proposing noisy withdrawals

151. Cf. supra Section V.A. (describing the primary role of management in retaining counsel in the current market for legal services).

152. As we continue to study corporate governance in the wake of Enron, additional structural changes related to boards may be necessary, such as changes to the nomination and removal process. The SEC's attorney responsibility rules implicitly recognize the value of structural mechanisms to improve legal compliance by suggesting (but not mandating) the creation of "qualified legal compliance committees" at corporations. See Adopted SEC Rules, supra note 4.

153. See Elizabeth Mertz, Legal Ethics in the Next Generation: The Push for a New Legal Realism, LAW \& SOC. INQUIRY 237 (1998) (introducing articles discussing relationship of Kaye Scholar law firm and savings and loan crisis).

154. In 2002, House Minority Leader Richard Gephardt introduced legislation contemplating attorney disclosures to law enforcement officials. See H.R. 5160,107 th Cong., 2d Sess., $\$ 431$ (introduced by Rep. Gephardt on July 18, 2002) 
and affirmative disavowals of filings by attorneys, the SEC has shown a willingness to move down this path. ${ }^{155}$

The purpose of this Article is not to defend attorney conduct in connection with the recent corporate scandals, but to evaluate whether mandatory reporting up is an appropriate solution. We suggest that it is not. Although attorneys should not facilitate fraud, mandatory reporting up is poorly tailored to address problems like those that plagued Enron. Moreover, in the absence of substantial changes in the incentives of lawyers and other corporate actors, the new legislation is unlikely to change lawyer behavior substantially.

More generally, the adoption of Section 307 in reaction to Enron's collapse raises questions about the merits of attempting to reform internal corporate decision-making through attorney conduct rules implemented by federal regulators. Instead, we argue for reforms that increase incentives for officers and directors-those who control access to corporate information and the corporation's course-to demand high quality services from their counsel. Lawyers have a critical role to play in preventing future Enrons. But only the lead actors in our system of corporate governance-directors and officers-can help lawyers to realize that role fully.

(involving federal government directly with $\mathrm{ABA}$ ethics rules by calling for study by Comptroller General of $A B A$ rules that includes consideration of whether issuer attorneys should disclose wrongdoing to law enforcement authorities). Moreover, additional attorney obligations might be based on aggressive application of moneylaundering rules to attorneys. See Stephanie Francis Cahill, A.B.A. J. Rep., Sept. 13, 2002, available at http://www.abanet.org/journal/ereport/s13gate.html (noting ABA Task Force on Gatekeeper Regulation and Profession opposed laws requiring lawyers to file reports of clients' suspicious transactions in response to proposals by Paris-based international group, Financial Action Task Force on Money Laundering); see also Edward J. Krauland \& Stéphane Lagonico, Latryers and Anti-Money Laundering: The Gatekeeper Initiative, 31:4 INT'L L. NEws 1 (2002) (discussing lawyers as gatekeepers to prevent criminal actions in corporations); James Roselle, Combating Money Laundering and Terrorist Activity: The Lauyer's Role and Recent SILP/ABA Initiatives, 31:4 INT'L L. News 1 (2002) (discussing attorney's duty to recognize and report potentially criminal activity).

155. See Proposed Reporting Out Rule, supra note 4 (reviewing appropriate withdrawal procedures). 